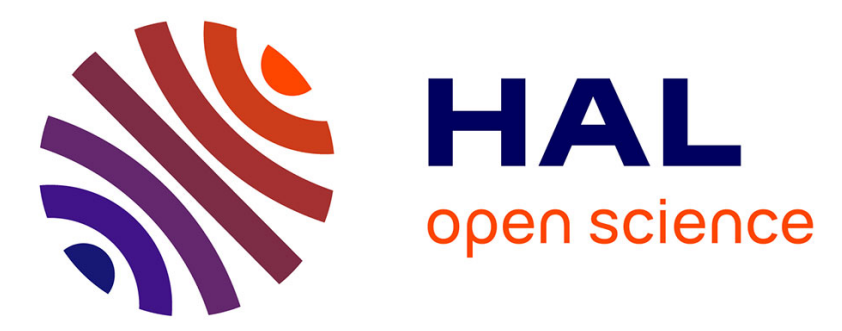

\title{
5-HT2A receptor signalling through phospholipase D1 associated with its carboxy-terminal tail
}

Zoe Barclay, Louise Dickson, Derek Robertson, Melanie Johnson, Pamela Holland, Roberta Rosie, Liting Sun, Sue Fleetwood-Walker, Eve M Lutz, Rory Mitchell

\section{To cite this version:}

Zoe Barclay, Louise Dickson, Derek Robertson, Melanie Johnson, Pamela Holland, et al.. 5-HT2A receptor signalling through phospholipase D1 associated with its carboxy-terminal tail. Biochemical Journal, 2011, 436 (3), pp.651-660. 10.1042/BJ20101844 . hal-00596269

\section{HAL Id: hal-00596269 \\ https://hal.science/hal-00596269}

Submitted on 27 May 2011

HAL is a multi-disciplinary open access archive for the deposit and dissemination of scientific research documents, whether they are published or not. The documents may come from teaching and research institutions in France or abroad, or from public or private research centers.
L'archive ouverte pluridisciplinaire HAL, est destinée au dépôt et à la diffusion de documents scientifiques de niveau recherche, publiés ou non, émanant des établissements d'enseignement et de recherche français ou étrangers, des laboratoires publics ou privés. 


\section{5-HT $2 \mathrm{~A}$ receptor signalling through phospholipase D1 associated with its carboxy-terminal tail}

Zoë BARCLAY*, Louise DICKSON*, Derek N. ROBERTSON*,a, Melanie S. JOHNSON*,b, Pamela J. HOLLAND*, Roberta ROSIE ${ }^{\dagger}$, Liting SUN ${ }^{\dagger}$, Sue FLEETWOOD-WALKER ${ }^{\dagger}$, Eve M. LUTZ ${ }^{\star \star}$ and Rory MITCHELL ${ }^{*}, 1$

* Centre for Integrative Physiology, School of Biomedical Sciences, Hugh Robson Building, University of Edinburgh, EH8 9XD, UK, ${ }^{\dagger}$ Centre for Neuroregeneration, School of Biomedical Sciences, Chancellor's Building, University of Edinburgh, EH16 4SB, UK and ${ }^{\star \star}$ Strathclyde Institute of Pharmacy and Biomedical Sciences, University of Strathclyde, Glasgow, G1 1XW, UK.

1 To whom correspondence should be addressed: Rory Mitchell, Centre for Integrative Physiology, School of Biomedical Sciences, University of Edinburgh, Hugh Robson Building, 9 George Square, EH8 9XD, UK. Tel: +44 131650 3550; Fax: +44 131650 6527; E-mail: rory mitchell@ed.ac.uk

\section{Synopsis:}

The 5-hydroxytryptamine-2A receptor $\left(5-\mathrm{HT}_{2 A} \mathrm{R}\right)$ is a $\mathrm{G}$ protein-coupled receptor (GPCR) that is implicated in the actions of hallucinogens and represents a major target of atypical antipsychotic agents. In addition to its classical signalling though phospholipase C (PLC), the receptor can activate several other pathways, including ARF-dependent activation of phospholipase D (PLD), which appears to be achieved through a mechanism independent of heterotrimeric $G$ proteins. We show here that wild-type and inactive constructs of PLD1 (but not PLD2) respectively facilitate and inhibit ARF-dependent PLD signalling by the $5-\mathrm{HT}_{2 \mathrm{~A}} \mathrm{R}$. Further we demonstrate that PLD1 specifically co-immunoprecipitates with the receptor and binds to a distal site in GST-fusion protein constructs of its carboxy-terminal tail that is distinct from the ARF interaction site, thereby suggesting the existence of a functional ARF:PLD signalling complex directly associated with this receptor. This reveals the spatial co-ordination of an important GPCR, transducer and effector into a physical complex that is likely to reinforce the impact of receptor activation on a heterotrimeric $G$ protein-independent signaling pathway. Signalling of this receptor through such non-canonical pathways may be important to its role in particular disorders.

\section{Short Title: PLD signalling complex associated with the 5-HT ${ }_{2 \mathrm{~A}} \mathrm{R}$}

Keywords: 5- $\mathrm{HT}_{2 \mathrm{~A}}$ receptor; phospholipase D; signalling complex; ADP-ribosylation factor; coimmunoprecipitation; GST-fusion protein; schizophrenia.

\section{Footnotes:}

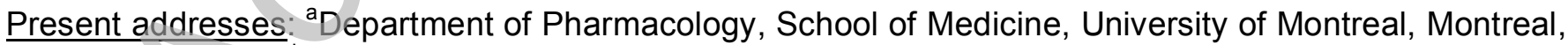
H3C 3J7, Canada. ${ }^{b}$ Deceased.

Abbreviations: 5-HT, 5-hydroxytryptamine; ARF, ADP-ribosylation factor; BFA, brefeldin A; BSA, bovine serum albumin; CHAPS, (3-[(3-cholamidopropyl)dimethylammonio]-1-propanesulphonate); ct, carboxylterminal; DMEM, Dulbecco's modified minimum essential medium; dpm, disintegrations per minute; EBSS, Earle's balanced salt solution; EGF, epidermal growth factor; GPCR, G protein-coupled receptor; GST, glutathione S-transferase; HA, haemagglutinin; HRP, horseradish peroxidase; i, intracellular loop; 
IP, immunoprecipitation; PBS, phosphate-buffered saline; PDBu, phorbol 12,13-dibutyrate; PI, protease inhibitor cocktail III, Calbiochem; PKC, protein kinase C; PLA 2 , phospholipase $A_{2}$; PLC, phospholipase C; PLD, phospholipase D; PrC, Protein C; PtdBut, phosphatidyl butanol; Ptdlns $(4,5) \mathrm{P}_{2}$, phosphatidylinositol 4,5-bisphosphate; SEM, standard error of the mean; tm, transmembrane domain.

\section{INTRODUCTION}

The $5-\mathrm{HT}_{2 \mathrm{~A}} \mathrm{R}$ is a $\mathrm{G}$ protein-coupled receptor (GPCR) of particular clinical interest due to its reported involvement in hallucinogenic and antipsychotic drug activity, thus implicating it as a potential therapeutic target for the treatment of various neuropsychiatric disorders, in particular schizophrenia [1]. It is widely accepted that the $5-\mathrm{HT}_{2 \mathrm{~A}} \mathrm{R}$ signals through the heterotrimeric $\mathrm{G}$ proteins, $\mathrm{G}_{\mathrm{q} / 11}$, to activate phospholipase $\mathrm{C}$ (PLC), thereby mobilising $\mathrm{Ca}^{2+}$ and activating protein kinase $\mathrm{C}$ (PKC) [2]. The third intracellular loop (i3) of the receptor is reported to interact directly with and activate $G \alpha_{q}$ [3].

There is evidence that the $5-\mathrm{HT}_{2 A} \mathrm{R}$ can also utilise various alternative signalling pathways. These include Src (through a route that may involve $\mathrm{G}_{\alpha_{\mathrm{i} / \mathrm{o}}}$-associated $\mathrm{G} \beta \gamma$ subunits [4]), ERK (through routes that are dependent on Src, epidermal growth factor (EGF) receptor transactivation or arrestin; [5-8]), phospholipase $A_{2}\left(P L A_{2}\right.$; through routes that may involve $G \alpha_{i / 0}$-associated $G \beta \gamma$-mediated ERK activation and $\mathrm{G}_{12 / 13}-$ mediated p38 activation [9, 10]), JAK2/STAT3 [11], Akt [12], GSK3 $\beta$ [13] and phospholipase $D$ (PLD) [14-16]. Some of these pathways show partially distinct pharmacologies and receptor reserves in comparison to the classical PLC pathway $[4,9,17,18]$. The 5- $\mathrm{HT}_{2 \mathrm{~A}} \mathrm{R}$, like a number of other GPCRs in a variety of cell types, can activate PLD through a route dependent on the small G protein ADPRibosylation Factor (ARF), via a mechanism that may involve direct association of ARF with the GPCR $[14,15,19-21]$. Our initial demonstration that certain GPCRs could directly couple to small $\mathrm{G}$ proteins [14] represents an important example of the developing concept of heterotrimeric $G$ protein-independent signalling by GPCRs [22-24].

We have recently shown that the $5-\mathrm{HT}_{2 \mathrm{~A}} \mathrm{R}$ specifically interacts with ARF1 but not with ARF6 and that residues Asn376-Asn384 of the $5-\mathrm{HT}_{2 \mathrm{~A}} \mathrm{R}$, located at the junction between the $7^{\text {th }}$ transmembrane $(\mathrm{tm})$ domain and the carboxy-terminal tail (ct), are critical to ARF1 binding and ARF1-dependent PLD activation [15, 16]. This region contains a conserved Asn-Pro-x-x-Tyr motif (residues Asn376-Tyr380), previously demonstrated to be involved in enabling ARF-dependent PLD activation [14], ARF1/6 selectivity [16] and agonist-mediated GPCR internalization [3].

In the present study we further show that PLD can also associate directly with the $5-\mathrm{HT}_{2 \mathrm{~A}} \mathrm{R}$, at a location in the ct domain distinct from the ARF1 binding site, suggesting the existence of a 5$\mathrm{HT}_{2 \mathrm{~A}} \mathrm{R}$ :ARF:PLD signalling complex. This is consistent with reports of PLD binding to the $\mu$-opioid receptor [25], mGluR1 metabotropic glutamate receptor [26] and $M_{3}$ muscarinic receptor (unpublished observations) and provides the first information on the site of PLD interaction within a GPCR.

\section{EXPERIMENTAL}

\section{Cell culture and transfection}

COS7 cells were maintained in culture in Dulbecco's modified minimum essential medium (DMEM; Invitrogen) containing $10 \%$ normal calf serum (Harlan) and $100 \mathrm{U} / \mathrm{ml}$ penicillin and $100 \mu \mathrm{g} / \mathrm{ml}$ streptomycin (Invitrogen). Cells were grown to 60-80\% confluency and sub-cultured twice weekly. Cells were seeded into 12-well plates (PLD and PLC assays) or $75 / 175 \mathrm{~cm}^{2}$ flasks (coimmunoprecipitation and glutathione S-transferase (GST)-fusion protein studies) and allowed to reach $60 \%$ confluency (after $\sim 24 \mathrm{~h}$ ) before transfections were performed, with combinations of cDNAs or empty vector where appropriate. After transfer to DMEM containing $2 \%$ Ultroser G (Pall Biosepra), 
transfections were carried out using GeneJuice (Merck Chemicals Ltd.) or FuGENE 6 (Roche Applied Science) according to the manufacturers' instructions and cells were used $72 \mathrm{~h}$ after transfection.

\section{Plasmids and mutagenesis}

The experiments utilised Protein $\mathrm{C}$ epitope-tagged human $(\mathrm{h})$ 5-hydroxytryptamine-2A receptor (PrC-5$\mathrm{HT}_{2 \mathrm{~A}} \mathrm{R}$; [15]; haemagglutinin (HA) epitope-tagged wild-type ARF1-HA and ARF6-HA (from Julie Donaldson, NIH); HA epitope-tagged PLD isoforms and mutants (from Mike Frohman, Stony Brook University: wild-type HA-PLD1 and HA-PLD2; catalytically inactive HA-PLD1(Lys898Arg) and HAPLD2(Lys758Arg)] and an ARF-selective construct, PLD1(PIM87/lle870Arg) [27]. The cDNA clone for human GTP-resistant negative mutant $G \alpha_{q}(G \ln 209 L e u / A s p 277 A s n)$ [28] was obtained from the Missouri S\&T cDNA Resource Center and those for the mouse $(m)$ GnRHR and negative mutant RhoA(Thr19Asn) were from Stuart Sealfon (Mount Sinai School of Medicine) and Gary Bokoch (The Scripps Research Institute) respectively. GST-fusion protein constructs of h5-HT $2 \mathrm{R}$-i3(Ile258-Gly326), ct(Asn376-Val471) and -ct(Lys385-Val471) have been described previously [15]. To prepare the additional truncated 5- $\mathrm{HT}_{2 \mathrm{~A}} \mathrm{Rct}$ constructs, cDNA sequences encoding residues Asn376-GIn428, Asn376-Thr438, Asn376-Cys470 of the wild-type 5- $\mathrm{HT}_{2 \mathrm{~A}} \mathrm{R}$ were PCR-amplified using appropriate primers and Taq polymerase (Promega). The resulting PCR products were purified using the Wizard DNA cleanup system (Promega) and sub-cloned into the pGEM-T Easy vector (Promega), prior to sequence analysis. Clones containing the appropriate sequences were digested with $B a m \mathrm{HI}$ and EcoRI, and the inserts sub-cloned into the pGEX-2T vector (GE Healthcare). Finally the BamHI sites were modified with Mung bean nuclease, as previously described [15] and the open reading frame checked by sequence analysis.

\section{PLC assays}

All chemicals and reagents were obtained from Sigma unless otherwise indicated. Medium was removed from transfected cells and replaced with Earle's balanced salt solution (EBSS; $0.5 \mathrm{ml}$; Invitrogen) containing HEPES (10 mM, pH 7.5), glucose $(0.18 \%)$ and $\left[{ }^{3} \mathrm{H}\right]$ inositol $(0.75 \mu \mathrm{Ci} /$ well; Perkin Elmer Biosciences). After $18 \mathrm{~h}$, the medium was replaced with fresh medium additionally containing bovine serum albumin (BSA; $0.2 \%$ ). Cells were pre-incubated for 15 min with lithium chloride (10 mM) prior to 5-HT addition. After $30 \mathrm{~min}$ (unless otherwise indicated), reactions were terminated by the removal of medium and the addition of ice-cold formic acid $(1 \mathrm{ml}, 10 \mathrm{mM})$, with plates left on ice for at least $1 \mathrm{~h}$ to ensure lysis. $\left[{ }^{3} \mathrm{H}\right]$ inositol phosphates $\left(\left[{ }^{3} \mathrm{H}\right] \mathrm{InsP}\right)$ were separated by anion exchange chromatography as previously described [14].

\section{PLD assays}

Medium was removed from transfected cells in 12-well plates and replaced with DMEM $(0.5 \mathrm{ml})$ containing $\left[{ }^{3} \mathrm{H}\right]$ palmitic acid $(1.5 \mu \mathrm{Ci} /$ well; Perkin Elmer Biosciences). After $18 \mathrm{~h}$, the medium was replaced with minimum essential medium $(0.5 \mathrm{ml})$ containing HEPES $(25 \mathrm{mM}, \mathrm{pH} 7.5)$ and fatty acid-free BSA $(0.5 \%)$. To allow assessment of the transphosphatidylation activity of PLD, butan-1-ol (30 mM) was added to each well, immediately followed by the addition of agonist. Responses were terminated after 20 min (unless otherwise stated) by the removal of medium and addition of ice-cold methanol ( 0.5 $\mathrm{ml} /$ well). Phospholipids were extracted and $\left[{ }^{3} \mathrm{H}\right]$ phosphatidyl butanol $\left(\left[{ }^{3} \mathrm{H}\right] \mathrm{PtdBut}\right)$ was separated on thin layer chromatography plates (LK5D; Whatman) as described previously [14]. For experiments on PLD responses in native tissues [14, 29], prefrontal cortex was rapidly removed from male Wistar rats and immersed in ice-cold, oxygenated $\mathrm{Ca}^{2+}$-free Krebs-Henseleit buffer additionally containing HEPES (10 $\mathrm{mM}, \mathrm{pH} 7.4)$, sodium pyruvate $(0.5 \mathrm{mM})$, glutathione $(5 \mu \mathrm{M})$, creatine phosphate $(2 \mathrm{mM})$, magnesium chloride $(5 \mathrm{mM})$ and sodium kynurenate $(1 \mathrm{mM})$. Minislices $(150 \times 150 \mu \mathrm{m})$ were prepared using a Mcllwain tissue slicer [30] and resuspended in fresh buffer. After $10 \mathrm{~min}$, the medium was replaced with cold oxygenated medium lacking magnesium and kynurenate but with $2 \mathrm{mM}$ calcium chloride and the 
minislice suspensions were aliquoted into 24 -well plates. $\left[{ }^{3} \mathrm{H}\right]$ palmitic acid was added $(1.5 \mu \mathrm{Ci} /$ well $)$ and the plates incubated for $3 \mathrm{~h}$ at $37{ }^{\circ} \mathrm{C}$ under $95 \% \mathrm{O}_{2}: 5 \% \mathrm{CO}_{2}$ prior to assay and analysis as above.

\section{GST-fusion protein studies}

GST-5-HT $2 \mathrm{~A} R-\mathrm{i} 3(258-326), \quad-\operatorname{ct}(376-428), \quad-\operatorname{ct}(376-438), \quad-\operatorname{ct}(376-470), \quad-\operatorname{ct}(376-471), \quad-\operatorname{ct}(385-471)$ constructs or empty vector were transformed into BL21-RIL bacterial cells, which were then grown up in standard $2 x$ yeast extract/tryptone/ $\mathrm{NaCl}$ medium with $2 \%$ glucose added. When the cells had reached an $\mathrm{A}_{600}$ of $0.6-0.8$ units $/ \mathrm{ml}$, fusion protein expression was induced by incubation with $0.5 \mathrm{mM}$ isopropyl- $\beta$ D-thiogalactoside $\left(3 \mathrm{~h}, 37^{\circ} \mathrm{C}\right.$; Invitrogen). Cells were harvested by centrifugation $\left(7500 \mathrm{~g}, 10 \mathrm{~min}, 4^{\circ} \mathrm{C}\right)$, lysed with BugBuster reagent $(1 \mathrm{ml} / 50 \mathrm{ml}$ of original cell suspension, $10 \mathrm{~min}$; Merck) and again centrifuged $\left(12,000 \mathrm{~g}, 25 \mathrm{~min}, 4^{\circ} \mathrm{C}\right)$. The bacterial supernatant was then incubated for $30 \mathrm{~min}$ at room temperature with glutathione-sepharose 4B beads (GE Healthcare; $200 \mu \mathrm{l}$ 1:1 suspension in phosphatebuffered saline (PBS) with 1:100 protease inhibitor cocktail set III (PI; Calbiochem)/1 ml supernatant), after which the matrix was washed extensively with PBS. To prepare ARF-and PLD-enriched cellular extracts, the medium was removed from flasks of transfected COS7 cells and replaced with $2 \mathrm{ml}$ ice-cold extraction buffer (ARF buffer: PBS with $1 \mathrm{mM}$ dithiothreitol, $1 \mathrm{mM}$ sodium orthovanadate, 1:100 PI; PLD buffer: $20 \mathrm{mM}$ HEPES $\mathrm{pH} 7.4,150 \mathrm{mM} \mathrm{NaCl}, 20 \%$ glycerol, $1 \%$ CHAPS (3-[(3cholamidopropyl)dimethylammonio]-1-propanesulphonate), $1 \%$ sodium deoxycholate, $1 \mathrm{mM}$ sodium orthovanadate, 1:100 PI), after which the flasks were left on ice for $45 \mathrm{~min}$. Prior to centrifugation the ARF extracts were homogenised with an Ystral homogeniser (Scientific Industries; setting 3, $15 \mathrm{~s}$ ). The lysates were transferred to eppendorf tubes and centrifuged $\left(12,000 \mathrm{~g}, 15 \mathrm{~min}, 4{ }^{\circ} \mathrm{C}\right)$ to remove particulate material. The washed GST-fusion protein-bead complexes were then incubated overnight $\left(4{ }^{\circ} \mathrm{C}\right.$, with rotation) with ARF1-HA- or HA-PLD1-enriched cellular extracts $(200 \mu \mathrm{l}$ of extract added along with $200 \mu \mathrm{l}$ PBS or extraction buffer as indicated). In some experiments, extracts and beads were incubated for $12 \mathrm{~h}$ followed by extensive washing of the beads and a further incubation (12 h) with a second extract. Beads were then washed twice in ice-cold buffer A (PBS containing $20 \%$ glycerol, $1 \%$ CHAPS, $1 \%$ sodium deoxycholate, $0.5 \mathrm{mM}$ EDTA) with 1:100 PI, followed by three washes with diluted buffer A (1:20 in PBS; 1:100 PI). Retained proteins were detached from the beads by the addition of 50 $\mu$ l Laemmli buffer (2\% sodium dodecyl sulphate, $5 \%$ mercaptoethanol, $20 \mathrm{mM}$ Tris- $\mathrm{HCl} \mathrm{pH} 7.4$ ) and heating to $70{ }^{\circ} \mathrm{C}$ for $5 \mathrm{~min}$.

\section{Immunoprecipitation studies}

Transfected COS7 cells were serum-deprived for $4 \mathrm{~h}$ and washed with Hanks' balanced salt solution (10 $\mathrm{ml}$; Invitrogen), prior to the addition of IP buffer (HEPES $20 \mathrm{mM} \mathrm{pH} \mathrm{7.5,} \mathrm{NaCl} 150 \mathrm{mM}, 20 \%$ glycerol, 1 $\%$ CHAPS, $0.5 \%$ sodium deoxycholate, $1 \mathrm{mM}$ sodium orthovanadate and $1: 100 \mathrm{Pl} ; 1 \mathrm{ml} / 75 \mathrm{~cm}^{2}$ flask). After $45 \mathrm{~min}$ incubation on ice, extracts were centrifuged at $\left.12,000 \mathrm{~g} \mathrm{(15} \mathrm{min,} 4^{\circ} \mathrm{C}\right)$ to remove particulate material and the supernatants were pre-cleared with Protein G-sepharose 4B beads (20 $\mu$ l of $1: 1$ suspension in IP buffer; incubation: $45 \mathrm{~min}, 4{ }^{\circ} \mathrm{C}$, with rotation). Samples were briefly centrifuged and the supernatants were incubated with primary antibodies (mouse anti-Protein C (PrC) tag; HPC4, Roche Applied Bioscience or mouse non-immune $\mathrm{lgG}$ ) and $20 \mu \mathrm{l} / \mathrm{ml}$ Protein G-sepharose 4B suspension (incubation: overnight, $4{ }^{\circ} \mathrm{C}$, with rotation). Beads were collected by centrifugation and washed three times with IP buffer prior to the addition of Laemmli buffer $(40 \mu \mathrm{l} / \mathrm{ml}$ of original supernatant).

\section{Western blots}

Using the NuPAGE Surelock Mini-cell system (Invitrogen), samples and original supernatants (to monitor input levels) from immunoprecipitation and GST studies were run on 4 - $12 \%$ Bis-Tris gels, which were subsequently blotted onto polyvinylidene fluoride membrane (Immobilon- $\mathrm{P}^{\mathrm{SQ}}$; Millipore). Detection antibodies used in GST-fusion protein studies were: goat anti-GST (GE Healthcare) used with horseradish peroxidase (HRP)-linked donkey anti-goat/sheep IgG (Millipore) and HRP-linked rat 
monoclonal anti-HA (3F10; Roche). For co-immunoprecipitation studies, detection antibodies used were 3F10 and HRP-linked mouse anti-PrC tag (HPC4, Roche). The binding of HRP-linked antibodies to membranes was detected by enhanced chemiluminescence using LumiGLO (Cell Signalling Technology).

\section{Ligand binding, cell surface biotinylation and plasma membrane capture}

Serum substitute was removed for $4 \mathrm{~h}$ prior to experiments. For membrane ligand binding, cells were harvested in ice-cold ketanserin binding buffer $(50 \mathrm{mM}$ Tris, $5 \mathrm{mM} \mathrm{MgCl}, 1 \mathrm{mM} \mathrm{EGTA}$; pH 7.2) supplemented with 1:100 PI and disrupted with an Ystral homogeniser (setting 3, 15 s). Lysates were centrifuged (10 min, $2000 \mathrm{~g}, 4{ }^{\circ} \mathrm{C}$ ), to pellet nuclear debris. The supernatants were further centrifuged (30 min, $12,000 \mathrm{~g}, 4^{\circ} \mathrm{C}$ ) to pellet microsomal membranes, which were washed before resuspension by trituration. Membranes were incubated with $0.8 \mathrm{nM}\left[{ }^{3} \mathrm{H}\right]$ ketanserin $(72.2 \mathrm{Ci} / \mathrm{mmol})$ and a range of concentrations of unlabelled ketanserin $(0.1-300 \mathrm{nM})$ for homologous displacement, or $10 \mu \mathrm{M}$ mianserin to determine non-specific binding (60 min, $37^{\circ} \mathrm{C}$ ). Binding was quenched with ice-cold buffer and membranes pelleted by centrifugation $\left(20 \mathrm{~min}, 12,000 \mathrm{~g}, 4{ }^{\circ} \mathrm{C}\right)$. The supernatant was aspirated and $\left[{ }^{3} \mathrm{H}\right]$ ketanserin bound to the pellet was measured by scintillation counting. Non-linear curve fitting was used to derive $K_{d}$ and $B_{\max }$ values (GraphPad Prism 4). Protein concentrations were determined using the Pierce BCA Protein Assay Kit.

Cell surface biotinylation was carried out using a membrane-impermeant covalent agent, biotinamidocaproic acid 3-sulpho-N-hydroxysuccinimide ester; NHS-sulpho-biotin; Pierce) and the capture of solubilised biotinylated proteins on (reversibly binding) monomeric avidin agarose beads, following the manufacturers' protocols [31]. Cells were washed with PBS and then incubated with $1 \mathrm{mM}$ NHS-sulpho-biotin in PBS $\left(2 \mathrm{~h}, 4{ }^{\circ} \mathrm{C}\right)$, before its removal and quenching with glycine $(75 \mathrm{mM})$ in PBS (10 min, $4{ }^{\circ} \mathrm{C}$ ). After washing in PBS, cells were solubilised in $1 \%$ CHAPS, $0.5 \%$ sodium deoxycholate, $1: 100 \mathrm{PI}, \mathrm{PBS}$ with $10 \%$ glycerol). Following centrifugation $\left(20 \mathrm{~min}, 12,000 \mathrm{~g}, 4{ }^{\circ} \mathrm{C}\right)$ aliquots of the supernatant were incubated with monomeric avidin agarose beads $\left(1 \mathrm{~h}, 4^{\circ} \mathrm{C}\right)$ with rolling, to bind biotin. The beads were then washed before biotinylated proteins were eluted using $2 \mathrm{mM}$ biotin in PBS (30 min, $4{ }^{\circ} \mathrm{C}$ ) with rolling. Total and biotinylated receptor levels were assessed by incubating aliquots of lysate and avidin agarose eluate respectively with $0.8 \mathrm{nM}\left[{ }^{3} \mathrm{H}\right]$ ketanserin and $10 \mu \mathrm{M}$ mianserin to determine non-specific binding as described above. Binding was terminated by protein precipitation through the addition of $18 \%$ polyethylene glycol-8000 in PBS at $4{ }^{\circ} \mathrm{C}$ with $0.003 \%$ bovine $\gamma$-globulin as a carrier. After vigorous vortexing, tubes were kept on ice for $15 \mathrm{~min}$ before centrifugation $\left(20 \mathrm{~min}, 12,000 \mathrm{~g}, 4^{\circ} \mathrm{C}\right)$. $\left[{ }^{3} \mathrm{H}\right]$ ketanserin associated with the pellets was measured by scintillation counting.

For plasma membrane isolation prior to co-immunoprecipitation we utilised a recent method [32] for selective capture using biotinylated lectin (Concanavalin A-biotin, Acris antibodies $\mathrm{GmbH}$ ) immobilised on Streptavidin-conjugated T1-Dynabeads (Invitrogen) and prepared according to the manufacturers' instructions. COS7 cells expressing PrC-5- $\mathrm{HT}_{2 \mathrm{~A}} \mathrm{R}$ and HA-PLD1 were homogenised in ice-cold ketanserin binding buffer with protease inhibitors $(20$ strokes mid-speed teflon-glass homogeniser) and centrifuged $\left(12,000 \mathrm{~g}, 15 \mathrm{~min}, 4{ }^{\circ} \mathrm{C}\right)$. Pellets were resuspended in fresh buffer and incubated with derivatised beads $\left(75 \mathrm{~min}, 4{ }^{\circ} \mathrm{C}\right.$, with rolling). Beads with attached membranes were captured by magnet and unassociated membranes were kept on ice. Beads were extensively washed (six times) with Tris-buffered saline and the associated membranes were then eluted and solubilised by three 10 min incubations $\left(4{ }^{\circ} \mathrm{C}\right.$, with rolling) in HEPES $(50 \mathrm{mM}, \mathrm{pH} 7.4)$ with glycerol $(10 \%), \alpha$-methyl mannoside $(0.25 \mathrm{M}), 1: 100 \mathrm{PI}$, sodium fluoride $(1 \mathrm{mM})$, sodium orthovanadate $(1 \mathrm{mM})$, CHAPS $(1 \%)$, sodium deoxycholate $(0.5 \%)$. Unbound, flow-through membranes were incubated for 30 min with rolling in the same buffer. Samples were then centrifuged $\left(100,000 \mathrm{~g}, 60 \mathrm{~min}, 4{ }^{\circ} \mathrm{C}\right)$ before aliquots of supernatant were incubated with mouse monoclonal anti-HA (clone 12CA5, Roche, $3 \mu \mathrm{g} / \mathrm{ml}$ ) or nonimmune $\operatorname{lgG}\left(3 \mathrm{~h}, 4{ }^{\circ} \mathrm{C}\right.$, with rolling) and then addition of Protein G-sepharose 4B (50 $\mu \mathrm{l}, 50 \%$ suspension $/ \mathrm{ml}$ ) for a further $1 \mathrm{~h}$. Beads were collected and washed twice by centrifugation in Trisbuffered saline with glycerol (10\%). CHAPS (1\%) and sodium deoxycholate $(0.5 \%)$ and then once in 
ketanserin binding buffer with glycerol (10\%) before resuspension in the latter and aliquoting into the $\left[{ }^{3} \mathrm{H}\right]$ ketanserin binding assay (as above).

\section{Data analysis}

For PLC and PLD assays, data are presented as mean values \pm the standard error of the mean (SEM), from between 6 to 8 separate determinations. In GST-fusion protein studies, densitometric analysis of western blot films was performed using Image $\mathrm{J}$ software $(\mathrm{NIH})$. Statistical significance was determined by non-parametric tests to avoid assumptions about normal distribution of the data using the Friedman test with Dunn's post-hoc analysis or the Wilcoxon test (as appropriate), with $p<0.05$ as the criterion for significance (GraphPad Prism 4).

\section{RESULTS}

\section{5-HT $2 \mathrm{~A}$ R-mediated PLD activation primarily involves PLD1}

The contribution of specific PLD isoforms to 5- $\mathrm{HT}_{2 \mathrm{~A}} \mathrm{R}$-mediated PLD activation was initially determined in time-course studies, using COS7 cells transfected with PrC-5- $\mathrm{HT}_{2 \mathrm{~A}} \mathrm{R}$ and either wild-type PLD (HA-PLD1 or -PLD2), catalytically inactive PLD (HA-PLD1(Lys898Arg) or -PLD2(Lys758Arg)) or empty vector. Receptor stimulation with 5-HT $(3 \mu \mathrm{M})$ produced a rapid increase in $\left[{ }^{3} \mathrm{H}\right.$ ]PtdBut production with almost complete desensitisation observed within 10 min (Fig 1a, b), whereas 5-HT-stimulated PLC activation showed little desensitisation for up to 60 min [16]. Following receptor co-expression with wild-type PLD isoforms, a significant potentiation of $\left[{ }^{3} \mathrm{H}\right] \mathrm{PtdBut}$ production was observed at all time points with PLD1 only, with a maximum response at $10 \mathrm{~min}(7.67 \pm 0.57$ fold of basal) of more than double control values ( $3.41 \pm 0.25$ fold of basal; Fig. $1 \mathrm{a} ; \mathrm{p}<0.05$, Friedman and Wilcoxon tests, $n=8$ ). Correspondingly, upon expression of catalytically inactive mutant PLD isoforms, only the PLD1 mutant altered $5-H_{2 A} R-$ mediated PLD activation, with a significant reduction in $\left[{ }^{3} \mathrm{H}\right] \mathrm{PtdBut}$ production observed at all time points relative to control (mean maximum response reduced by $86 \%$; Fig. 1b; $p<0.05$, Friedman and Wilcoxon tests, $n=8$ ). Neither wild-type nor mutant PLD isoforms had any significant effect on agoniststimulated $\left[{ }^{3} \mathrm{H}\right]$ InsP production at $60 \mathrm{~min}$ (Fig. 1c) or at earlier time points (data not shown). To investigate $5-\mathrm{HT}_{2 \mathrm{~A}} \mathrm{R}$-mediated $\mathrm{PLD}$ activation in native tissues, minislices of prefrontal cortex were rapidly prepared in cold, oxygenated, protective medium and resuspended in modified Krebs-Henseleit buffer for labelling with $\left[{ }^{3} \mathrm{H}\right]$ palmitate prior to assay. Fig. 1d shows that the increase in $\left[{ }^{3} \mathrm{H}\right] \mathrm{PtdBut}$ production induced by the selective $5-\mathrm{HT}_{2} \mathrm{R}$ agonist $(\mathrm{R})$-2,5-dimethoxy-4-iodoamphetamine $((\mathrm{R})$-DOI [33]; $1 \mu \mathrm{M}, 20 \mathrm{~min})$ was inhibited by $67 \%(p<0.05, n=5)$ in the presence of the highly selective $5-\mathrm{HT} 2 \mathrm{~A} \mathrm{R}$ antagonist M100907 (MDL; [34]; Axon Medchem; $0.5 \mu \mathrm{M}$ with 10 min pre-incubation) indicating that the major part of the response was $5-H_{2} T_{2 A} R$-mediated. The response to (R)-DOI was also significantly inhibited (by 78\%) by the selective PLD1 inhibitor VU 0155069 (VU; [35]; Enzo Life Sciences; $0.5 \mu \mathrm{M}$ ) but not by the selective PLD2 inhibitor BML 280 (BML; [36]; Enzo; $5 \mu \mathrm{M}$ ), matching the PLD1 selectivity shown by the $5-\mathrm{HT}_{2 \mathrm{~A}} \mathrm{R}$ in our cell model system.

\section{The mechanism of $5-H_{2 A}$ R-mediated PLD activation in the presence or absence of additional PLD1 primarily involves ARF rather than alternative pathways}

We have previously demonstrated that $5-\mathrm{HT}_{2 \mathrm{~A}} \mathrm{R}$-mediated PLD but not PLC activation is specifically inhibited by dominant negative ARF1 but not ARF6 $[15,16]$. However, as the $5-H_{2 A} R$ is well known to couple through $\mathrm{G}_{\mathrm{q} / 11}$ to PLC activation we investigated whether its activation of PLD might be in part downstream of this pathway. Table 1 shows that PLD responses mediated by the $5-\mathrm{HT}_{2 \mathrm{~A}} \mathrm{R}$ or those amplified by co-transfection of additional PLD1 showed no significant attenuation in the presence of the GTP-insensitive negative mutant $\mathrm{G}_{\mathrm{q}}$ (GIn209Leu/Asp277Asn) [28], whereas in contrast, PLD responses of the GnRHR (a receptor that substantially utilises $G \alpha_{q / 11}$-dependent pathways of PLD activation [14]) 
were strongly attenuated $\left(\mathrm{p}<0.05\right.$, Wilcoxon test, $\mathrm{n}=6$ ). Correspondingly, $5-\mathrm{HT}_{2 \mathrm{~A}} \mathrm{R}$-mediated PLD activation in the absence or presence of additional PLD1 was unaltered by the PLC inhibitor U73122 (Table 2a). As PLD activation by some GPCRs may involve tyrosine kinases and the $5-\mathrm{HT}_{2 \mathrm{~A}} \mathrm{R}$ is known to activate Src $[4,37]$ we also investigated a number of tyrosine kinase inhibitors. However, agents selective for Src-family kinases (PP1, PP2, Src-inhibitor 1; Tocris Bioscience) and an inactive control (PP3; [38, 39] were without effect on 5- $\mathrm{HT}_{2 \mathrm{~A}} \mathrm{R}$-mediated PLD responses in the absence or presence of additional PLD1, as were broader spectrum tyrosine kinase inhibitors, AG 213 and genistein (Table 2a,b).

Further experiments were carried out to investigate the extent of involvement of other prominent activators of PLD1, PKC and small G proteins of the ARF and Rho families [40]. Selective inhibitors of PKC, bisindolylmaleimide 1 (BIM-1) and CGP 41251 were also shown to have no significant effect on 5$\mathrm{HT}_{2 \mathrm{~A}}$ R-mediated PLD activation, as were the $\mathrm{G} \alpha_{\mathrm{i} / \mathrm{o}}$ inhibitor, pertussis toxin and the inhibitor of $\mathrm{G}$ protein $\beta \gamma$ subunit-dependent signalling, gallein (Tocris Bioscience) [41] (Table 2c). Additionally, we used a dominant negative construct approach to assess whether RhoA (which can activate PLD1 by direct interaction with its carboxy-terminal domain [27] was playing a significant role here. The inactive, GTPexchange deficient mutant, RhoA (Thr19Asn) was without significant effect on $5-\mathrm{HT}_{2 \mathrm{~A}} \mathrm{R}$-mediated PLD activation despite clearly inhibiting PLD responses of the thrombin receptor (an Asp-Pro-x-x-Tyr, receptor with apparently ARF-independent PLD activation [14]; Table 3).

A mutant PLD1 construct has been reported in which sequence deletion and mutation abrogate its activation by PKC or RhoA but activation of the enzyme by ARF is spared [27]. Table 4 shows that cotransfection of this ARF-activation-specific mutant of PLD1, PLD1(PIM87/lle870Arg) with the 5-HT $2 A$ R caused marked and significant amplification of the PLD response to 5-HT ( $3 \mu \mathrm{M} ; \mathrm{p}<0.05$, Wilcoxon test) that was not significantly different to that achieved by wild-type PLD1. As a control, we examined phorbol ester-induced activation of PLD (since PLD1 activation by PKC is prevented in the PLD1(PIM87/lle870Arg) mutant). Phorbol 12,13-dibutyrate (PDBu)-induced PLD responses were significantly facilitated by co-transfection of wild-type PLD1 but not PLD1(PIM87/lle870Arg) $(p<0.05$, Wilcoxon test, $n=6)$. This evidence for ARF-dependence of PLD1 activation by the $5-H_{2 A} R$ is fully consistent with previous data with negative mutant ARF1 $[15,16]$.

\section{PLD1 co-immunoprecipitates with the $5-\mathrm{HT}_{2 \mathrm{~A}} \mathrm{R}$ in a complex primarily of plasma membrane origin}

To investigate the possibility of direct PLD1 interaction with the 5-HT $2 A$, their co-immunoprecipitation was investigated in COS7 cells expressing PrC-5-HT ${ }_{2 A} R$ and HA-PLD1. PLD1 was specifically associated with PrC tag-directed pulldowns but not non-immune IgG controls (Fig. 2a, bottom panel). Similar results were obtained in four further independent experiments. Input levels of PLD1 (Fig. 2a, upper panel) and immunoprecipitated receptor (Fig. 2a, middle panel) were monitored. Pilot experiments with PLD2 showed no specific association with PrC-5- $\mathrm{HT}_{2 \mathrm{~A}} \mathrm{R}$ but a degree of non-specific binding (data not shown). The time-course of PLD1 co-immunoprecipitation with the 5- $\mathrm{HT}_{2 \mathrm{~A}} \mathrm{R}$ was investigated through incubation with 5-HT $(10 \mu \mathrm{M})$ from $5-60 \mathrm{~min}$ but no statistically significant changes were detected $(\mathrm{n}=$ $6)$.

Specific binding of $\left[{ }^{3} \mathrm{H}\right]$ ketanserin to the PrC-5- $\mathrm{HT}_{2 \mathrm{~A}} \mathrm{R}$ was assessed by homologous displacement, with non-linear curve fitting revealing an affinity $\left(\mathrm{K}_{\mathrm{d}}\right)$ of $0.58 \pm 0.05 \mathrm{nM}$ and number of binding sites $\left(\mathrm{B}_{\max }\right)$ of $0.90 \pm 0.06 \mathrm{pmol} / \mathrm{mg}$ protein, $\mathrm{n}=4$ ). To confirm that the $\mathrm{PrC}-5-\mathrm{HT}_{2 \mathrm{~A}} \mathrm{R}$ mediating PLD responses was substantially expressed at the cell surface we used a previously described protocol $[15,31]$ involving cell surface biotinylation, solubilisation, capture and elution from monomeric avidin beads, then $\left[{ }^{3} \mathrm{H}\right]$ ketanserin binding to the recovered solubilised receptor, which revealed that $36.3 \pm 8.6 \%$ of the receptors were labelled and recovered in this way $(n=5)$.

In addition we utilised a recently described method involving avidin-conjugated magnetic beads derivatised with biotinylated concanavalin $A$ [32] to capture plasma membrane from COS7 cells expressing PrC-5- $\mathrm{HT}_{2 \mathrm{~A}} \mathrm{R}$ and $\mathrm{HA}-\mathrm{PLD1}$, prior to solubilisation, followed by $\mathrm{HA}$ tag-directed immunoprecipitation and assessment of specific $\left[{ }^{3} \mathrm{H}\right]$ ketanserin binding to the pulldowns. Over $72 \%$ of 
the specific $\left[{ }^{3} \mathrm{H}\right]$ ketanserin binding associated with HA-pulldowns in excess of non-immune IgG controls was recovered from the captured plasma membrane fraction rather than the (non-plasma membrane) flow-through (Fig. 2b).

\section{PLD1 binds to the 5-HT $2 \mathrm{~A}$ C-terminal tail, at a location distal to the ARF interaction site}

The interaction of PLD1 with specific regions of the $5-\mathrm{HT}_{2 \mathrm{~A}} \mathrm{R}$ was then examined using GST-fusion protein constructs comprising sections of the receptor C-terminal tail; full-length -ct(376-471), truncated ct(385-471) and i3, -i3(258-326) sequences. Following incubation with glutathione-sepharose beads, the bead-GST construct complexes were incubated with COS7 cell extracts enriched in HA-PLD1. Association of HA-PLD1 with the constructs was examined by HA immunoblot (Fig. 2C) and quantified using densitometry. Input levels of the GST-5-HT $2 \mathrm{~A} R \mathrm{~B},-5-\mathrm{HT}_{2 \mathrm{~A}} \mathrm{Rct}$ constructs and GST alone were similar, as shown by examining GST immunoreactivity (Fig. 2c, lower panel). Relative to the -ct(376471), PLD1 association with the $\operatorname{ct}(385-471)$ construct was clearly increased. PLD1 association with the i3(258-326) construct was minimal. PLD1 showed no discernible association with GST alone (Fig. 2c). Relative intensities of HA-PLD1 binding (ratio bound by construct to GST alone) to the -ct(376-471), ct(385-471) and -i3(258-326) constructs were 7.1, 11.5 and 3.4. PLD1 binding to the - $\operatorname{ct}(385-471)$ construct was significantly greater than to the complete - $\operatorname{ct}(376-471)$ construct and that to the -i3 (258326) construct was significantly less ( $<<0.05$, Wilcoxon test, $n=5)$. In contrast, ARF1-HA associated more robustly with the full length $-\operatorname{ct}(376-471)$ construct than the proximally-truncated form or the i3 construct [15].

\section{C-terminally truncated $5-\mathrm{HT}_{2 \mathrm{~A}}$ Rct constructs show reduced interaction with PLD1 but not ARF1}

To further delineate regions of the $5-\mathrm{HT}_{2 \mathrm{~A}} \mathrm{R}$ carboxy-terminal tail that are important for specific PLD association, a series of GST-5- $\mathrm{HT}_{2 \mathrm{~A}}$ Rct constructs of varying length were examined for their ability to bind HA-PLD1 and ARF1-HA. Full length GST-5-HT $2 \mathrm{~A} \operatorname{Rct}(376-471)$ and carboxy-terminally truncated $\operatorname{ct}(376-470)$, -ct(376-438) and - $\operatorname{ct}(376-428)$ constructs were captured on glutathione-sepharose beads and incubated with HA-PLD1 or ARF1-HA-enriched cellular extracts. HA-tagged proteins bound to the GST constructs were separated by Western blot and the extent of their binding was quantified by densitometric analysis (Fig. 3). Both HA-PLD1 and ARF1-HA displayed robust interactions with the full length -ct(376-471) construct. Removal of carboxy-terminal residues from the GST-5-HT $2 \mathrm{~A}$ Rt resulted in the clear attenuation of HA-PLD1 interaction, with HA-PLD1 immunoreactivity significantly reduced with the $-\operatorname{ct}(376-438)$ and $-\operatorname{ct}(376-428)$ constructs relative to the full length $5-\mathrm{HT}_{2 \mathrm{~A}} \mathrm{Rct}(\mathrm{p}<0.05$, Wilcoxon test, $\mathrm{n}=5$ ). Following removal of only Val471, at the extreme caboxy-terminus, a small (but not significant) reduction in the degree of HA-PLD1 binding was observed. In contrast, carboxy-terminal truncation of the 5- $\mathrm{HT}_{2 \mathrm{~A}} \operatorname{Rct}(376-471)$ construct had no significant effect on the level of associated ARF1HA immunoreactivity (Wilcoxon test, $n=6$ ).

\section{HA-PLD1 and ARF1-HA separately associate with the 5- $\mathrm{HT}_{2 \mathrm{~A}} \mathrm{Rct}$}

As both HA-PLD1 and ARF1-HA primarily associated with the 5-HT $2 A$ Rct domain, the possibility of interdependence in their binding was assessed. Following capture on glutathione-sepharose beads, the full length GST-5- $\mathrm{HT}_{2 \mathrm{~A}} \mathrm{Rct}(376-471)$ construct was incubated for two successive $12 \mathrm{~h}$ periods with paired combinations selected from HA-PLD1, ARF1-HA, ARF buffer and PLD buffer (Fig. 4). The initial association of HA-PLD1 with the GST-5- $\mathrm{HT}_{2 \mathrm{~A}} \mathrm{Rct}(376-471)$ construct did not alter subsequent binding of ARF1-HA to the receptor ct construct and similarly, the degree of HA-PLD1 binding to this construct was not changed by prior binding of ARF1-HA. Furthermore, it was clear in both cases that the binding of the second protein did not cause displacement of the previously bound protein. This experiment provided no evidence to suggest that interactions of ARF1 and PLD1 with the 5- $\mathrm{HT}_{2 \mathrm{~A}}$ Rct domain were either competitive nor co-dependent but should be interpreted with a degree of caution as it did not test the 
kinetics of simultaneous binding of ARF1 and PLD1 and further, there may be an excess of available binding sites for the two ligands on individual GST-ct molecules.

\section{DISCUSSION}

\section{PLD1 interaction with the 5-HT $2 \mathrm{~A}$ and mediation of its signalling output}

In earlier studies $[15,16]$ we showed that the small G protein ARF, in particular the ARF1 is oform, docks directly to the proximal ct domain of the $5-\mathrm{HT}_{2 \mathrm{~A}} \mathrm{R}$ and plays an important role in PLD activation by the receptor. We now show that PLD, in particular the PLD1 isoform, can also associate with the 5-HT ${ }_{2 A} R$ ct domain, but in this case to a more distal region. The current findings provide evidence for the existence of a putative signalling complex containing the core elements $5-\mathrm{HT}_{2 \mathrm{~A}} \mathrm{R}, \mathrm{ARF}$ and PLD. In functional signalling experiments, 5-HT-induced PLD responses of the 5- $\mathrm{HT}_{2 \mathrm{~A}} \mathrm{R}$ were selectively facilitated by transfection of additional PLD1 but not PLD2, and correspondingly were selectively inhibited by negative mutant (catalytically inactive) PLD1 but not PLD2, while none of the transfections modified PLC responses. These data suggest that PLD1 is the isoform predominantly involved in PLD responses of the $5-\mathrm{HT}_{2 \mathrm{~A}} \mathrm{R}$ expressed in COS7 cells. Corresponding experiments in prefrontal cortex with new selective inhibitors of PLD1 and PLD2 indicated a similarly preferential coupling to PLD1 by the 5-HT $2 \mathrm{~A} R$ in vivo. In cellular assays, these agents are reported to show $\mathrm{IC}_{50}$ values for PLD1 and PLD2 respectively of $11 \mathrm{nM}$ and $90 \mathrm{nM}$ with more than 160 fold and 20 fold selectivity for their preferred targets [35, 36]. Their use here at approximately 50 times the $\mathrm{IC}_{50}$ values in each case should have been adequate to reveal any role of either isozyme, given that their absolute potencies in mammalian tissues may not be identical to the values reported. We further explored whether any other pathways in addition to ARF contributed to these PLD responses. Earlier findings showed effective inhibition of PLD responses by negative mutant ARF1 and the ARF-GTP exchange factor inhibitor brefeldin A (BFA) [15]. Here, we demonstrated that PLD responses of the 5- $\mathrm{HT}_{2 \mathrm{~A}} \mathrm{R}$ alone or in the presence of additional PLD1 were apparently independent of $\mathrm{G}_{\alpha_{\mathrm{q} / 11}}, \mathrm{G} \alpha_{\mathrm{i} / \mathrm{o}}, \mathrm{G} \beta \gamma$ subunits, PLC, PKC, Src-family or other tyrosine kinases and RhoA. In addition, a mutant form of PLD1 with disrupted activation by PKC or RhoA (but maintained sensitivity to ARF) was able to amplify $5-\mathrm{HT}_{2 \mathrm{~A}} \mathrm{R}$ PLD responses to an extent comparable to that demonstrated by wild type PLD1. Although all pharmacological agents may have effects in addition to those at their primary targets, combined experiments with a range of different pharmacological and molecular tools implicate ARF1 but not other pathways in 5- $\mathrm{HT}_{2 \mathrm{~A}} \mathrm{R}$ coupling to PLD activation under the present conditions.

Matching the results of the signalling studies, co-immunoprecipitation experiments revealed specific association of PLD1 with the 5-HT $2 \mathrm{~A} R$. The receptor-associated PLD1 appeared to originate largely from the plasma membrane, consistent with evidence for its plasma membrane localization and/or stimulusinduced trafficking in PC12, chromaffin and COS7 cells [31, 42, 43]. This is in contrast to results with the $\mu$-opioid receptor [25] and the mGluR1 metabotropic glutamate receptor [26] where specific PLD2 interaction was reported, and is distinct from our findings with the $M_{3}$ muscarinic receptor where both PLD1 and PLD2 interact to a similar extent (unpublished observations). The differential selectivity shown by these receptors is likely to be due to sequence differences in the putative interaction site, which has been localised in the case of the $5-\mathrm{HT}_{2 \mathrm{~A}} \mathrm{R}$ to the distal part of the ct domain. PLD2 interaction may have a role in endocytosis [25, 26, 44, 45], whereas PLD1 may be important in intracellular trafficking as well as signalling $[31,46,47]$. In this study we found that agonist incubation produced no significant change in PLD1 co-immunoprecipitation with the $5-\mathrm{HT}_{2 \mathrm{~A}} \mathrm{R}$, at a time when ARF1 association was significantly increased [15]. This is consistent with our further data, which were unable to detect either competition or co-operativity between ARF and PLD binding to the $5-\mathrm{HT}_{2 \mathrm{~A}} \mathrm{R}$; observations contrasting with those at the $\mu$-opioid receptor where ARF facilitated PLD2 interaction [25]. Further support for the idea of independent interaction of ARF1 and PLD1 with the $5-H T_{2 A} R$ comes from experiments with truncated GST-fusion protein constructs of the 5- $\mathrm{HT}_{2 \mathrm{~A}} \mathrm{Rct}$ domain, which showed the 
ARF1 interaction site to be in the proximal region (376-384) whereas the PLD1 docking site is predominantly more distal (439-471).

Interestingly, phosphatidylinositol 4-phosphate 5-kinases (Ptdlns4P-5Ks), which are important in cellular phosphatidylinositol 4,5-bisphosphate $\left(P t d \operatorname{lns}(4,5) \mathrm{P}_{2}\right)$ synthesis, can be directly activated not only by ARFs but in addition, by the PLD product phosphatidic acid $[48,49]$ so might be activated during $5-\mathrm{HT}_{2 \mathrm{~A}} \mathrm{R}$ signalling through ARF1 or its downstream target, PLD1. As Ptdlns $(4,5) \mathrm{P}_{2}$ is an essential cofactor for PLD1, co-ordinated enhancement of Ptdlns4P-5K activity could be important in relaying or amplifying signals from the $5-\mathrm{HT}_{2 \mathrm{~A}} \mathrm{R}$ to PLD1 via ARF1. Whether Ptdlns4P-5Ks might physically associate together with ARF and PLD in complexes with the $5-\mathrm{HT}_{2 \mathrm{~A}} \mathrm{R}$ is unknown.

In summary, we have provided evidence for a novel partnership between the ct domain of the $5-\mathrm{HT}_{2 \mathrm{~A}} \mathrm{R}$ and PLD1, which in view of our previous demonstration that the PLD activator ARF is also docked to a different location within the $5-\mathrm{HT}_{2 \mathrm{~A}} \mathrm{Rct}$, suggests the possible presence of a functional $5-\mathrm{HT}_{2 \mathrm{~A}} \mathrm{R}: \mathrm{ARF}: \mathrm{PLD}$ signalling complex. This complex would provide the spatial organization to secure robust PLD signaling by the $5-\mathrm{HT}_{2 \mathrm{~A}} \mathrm{R}$ and focus its impact on downstream targets localised in the immediate vicinity of the receptor. Such non-canonical signaling pathways operated by the $5-\mathrm{HT}_{2 \mathrm{~A}} \mathrm{R}$ in neurons may play a part in mediating its psychotropic influence within the central nervous system. The present findings further emphasize the idea that certain GPCRs are able to signal through heterotrimeric G protein-independent pathways that may involve direct association of novel transducers and indeed also effector enzymes in functional signalling complexes with these receptors.

\section{ACKNOWLEDGEMENTS}

We are grateful to Julie Donaldson, Mike Frohman, Stuart Sealfon and Gary Bokoch for their generous gifts of constructs.

\section{FUNDING}

This work was supported by the Wellcome Trust (University Award 074817/Z/04 to RM) and the National Alliance for Research into Schizophrenia and Depression, NARSAD, USA (Independent Investigator Award to RM). ZB, DNR and LS were supported by studentships from BBSRC, MRC and the China Scholarship Council respectively.

\section{REFERENCES}

1 Dean, B. (2003) The cortical serotonin2A receptor and the pathology of schizophrenia: a likely accomplice. J. Neurochem. 85, 1-13

2 Hoyer, D., Clarke, D. E., Fozard, J. R., Hartig, P. R., Martin, G. R., Mylecharane, E. J., Saxena, P. R. and Humphrey, P. P. (1994) International Union of Pharmacology classification of receptors for 5-hydroxytryptamine (Serotonin). Pharmacol. Rev. 46, 157-203

3 Roth, B. L., Willins, D. L., Kristiansen, K. and Kroeze, W. K. (1998) 5-Hydroxytryptamine2family receptors (5-hydroxytryptamine2A, 5-hydroxytryptamine2B, 5-hydroxytryptamine2C): where structure meets function. Pharmacol. Ther. 79, 231-257

4 Gonzalez-Maeso, J., Weisstaub, N. V., Zhou, M., Chan, P., Ivic, L., Ang, R., Lira, A., BradleyMoore, M., Ge, Y., Zhou, Q., Sealfon, S. C. and Gingrich, J. A. (2007) Hallucinogens recruit specific cortical 5-HT(2A) receptor-mediated signaling pathways to affect behavior. Neuron 53, 439-452 
Banes, A., Florian, J. A. and Watts, S. W. (1999) Mechanisms of 5-hydroxytryptamine(2A) receptor activation of the mitogen-activated protein kinase pathway in vascular smooth muscle. J. Pharmacol. Exp. Ther. 291, 1179-1187

6 Quinn, J. C., Johnson-Farley, N. N., Yoon, J. and Cowen, D. S. (2002) Activation of extracellular-regulated kinase by 5-hydroxytryptamine(2A) receptors in PC12 cells is protein kinase $\mathrm{C}$-independent and requires calmodulin and tyrosine kinases. J. Pharmacol. Exp. Ther. 303, 746-752

7 Gooz, M., Gooz, P., Luttrell, L. M. and Raymond, J. R. (2006) 5-HT2A receptor induces ERK phosphorylation and proliferation through ADAM-17 tumor necrosis factor-alpha-converting enzyme (TACE) activation and heparin-bound epidermal growth factor-like growth factor (HBEGF) shedding in mesangial cells. J. Biol. Chem. 281, 21004-21012

8 Schmid, C. L., Raehal, K. M. and Bohn, L. M. (2008) Agonist-directed signaling of the serotonin 2A receptor depends on beta-arrestin-2 interactions in vivo. Proc. Natl. Acad. Sci. U. S. A. 105, 1079-1084

9 Berg, K. A., Maayani, S., Goldfarb, J., Scaramellini, C., Leff, P. and Clarke, W. P. (1998) Effector pathway-dependent relative efficacy at serotonin type $2 \mathrm{~A}$ and $2 \mathrm{C}$ receptors: evidence for agonist-directed trafficking of receptor stimulus. Mol. Pharmacol. 54, 94-104

10 Kurrasch-Orbaugh, D. M., Parrish, J. C., Watts, V. J. and Nichols, D. E. (2003) A complex signaling cascade links the serotonin2A receptor to phospholipase A2 activation: the involvement of MAP kinases. J. Neurochem. 86, 980-991

11 Guillet-Deniau, I., Burnol, A. F. and Girard, J. (1997) Identification and localization of a skeletal muscle serotonin 5-HT2A receptor coupled to the Jak/STAT pathway. J. Biol. Chem. 272, 14825-14829

12 Johnson-Farley, N. N., Kertesy, S. B., Dubyak, G. R. and Cowen, D. S. (2005) Enhanced activation of Akt and extracellular-regulated kinase pathways by simultaneous occupancy of Gq-coupled 5-HT2A receptors and Gs-coupled 5-HT7A receptors in PC12 cells. J. Neurochem. 92, 72-82

13 Abbas, A. I., Yadav, P. N., Yao, W. D., Arbuckle, M. I., Grant, S. G., Caron, M. G. and Roth, B. L. (2009) PSD-95 is essential for hallucinogen and atypical antipsychotic drug actions at serotonin receptors. J. Neurosci. 29, 7124-7136

14 Mitchell, R., McCulloch, D., Lutz, E., Johnson, M., MacKenzie, C., Fennell, M., Fink, G., Zhou, W. and Sealfon, S. C. (1998) Rhodopsin-family receptors associate with small G proteins to activate phospholipase D. Nature 392, 411-414

15 Robertson, D. N., Johnson, M. S., Moggach, L. O., Holland, P. J., Lutz, E. M. and Mitchell, R. (2003) Selective interaction of ARF1 with the carboxy-terminal tail domain of the 5-HT2A receptor. Mol. Pharmacol. 64, 1239-1250

16 Johnson, M. S., Robertson, D. N., Holland, P. J., Lutz, E. M. and Mitchell, R. (2006) Role of the conserved NPxxY motif of the 5-HT2A receptor in determining selective interaction with isoforms of ADP-ribosylation factor (ARF). Cell. Signal. 18, 1793-1800

17 Kurrasch-Orbaugh, D. M., Watts, V. J., Barker, E. L. and Nichols, D. E. (2003) Serotonin 5hydroxytryptamine $2 \mathrm{~A}$ receptor-coupled phospholipase $\mathrm{C}$ and phospholipase $\mathrm{A} 2$ signaling pathways have different receptor reserves. J. Pharmacol. Exp. Ther. 304, 229-237

18 Moya, P. R., Berg, K. A., Gutierrez-Hernandez, M. A., Saez-Briones, P., Reyes-Parada, M., Cassels, B. K. and Clarke, W. P. (2007) Functional selectivity of hallucinogenic phenethylamine and phenylisopropylamine derivatives at human 5-hydroxytryptamine (5HT) 2A and 5-HT2C receptors. J. Pharmacol. Exp. Ther. 321, 1054-1061

19 Fensome, A., Whatmore, J., Morgan, C., Jones, D. and Cockcroft, S. (1998) ADP-ribosylation factor and Rho proteins mediate fMLP-dependent activation of phospholipase $D$ in human neutrophils. J. Biol. Chem. 273, 13157-13164

20 Shome, K., Rizzo, M. A., Vasudevan, C., Andresen, B. and Romero, G. (2000) The activation of phospholipase D by endothelin-1, angiotensin II, and platelet-derived growth factor in 
vascular smooth muscle A10 cells is mediated by small $G$ proteins of the ADP-ribosylation factor family. Endocrinol. 141, 2200-2208

21 McCulloch, D. A., Lutz, E. M., Johnson, M. S., Robertson, D. N., MacKenzie, C. J., Holland, P. J. and Mitchell, R. (2001) ADP-ribosylation factor-dependent phospholipase D activation by VPAC receptors and a PAC(1) receptor splice variant. Mol. Pharmacol. 59, 1523-1532

22 Heuss, C. and Gerber, U. (2000) G-protein-independent signaling by G-protein-coupled receptors. Trends in Neurosci. 23, 469-475

23 Rajagopal, K., Lefkowitz, R. J. and Rockman, H. A. (2005) When 7 transmembrane receptors are not G protein-coupled receptors. J. Clin. Invest. 115, 2971-2974

24 Sun, Y., McGarrigle, D. and Huang, X. Y. (2007) When a G protein-coupled receptor does not couple to a $G$ protein. Mol. Biosystems 3, 849-854

25 Koch, T., Brandenburg, L. O., Schulz, S., Liang, Y., Klein, J. and Hollt, V. (2003) ADPribosylation factor-dependent phospholipase D2 activation is required for agonist-induced muopioid receptor endocytosis. J. Biol. Chem. 278, 9979-9985

26 Bhattacharya, M., Babwah, A. V., Godin, C., Anborgh, P. H., Dale, L. B., Poulter, M. O. and Ferguson, S. S. (2004) Ral and phospholipase D2-dependent pathway for constitutive metabotropic glutamate receptor endocytosis. J. Neurosci. 24, 8752-8761

27 Du, G., Altshuller, Y. M., Kim, Y., Han, J. M., Ryu, S. H., Morris, A. J. and Frohman, M. A. (2000) Dual requirement for rho and protein kinase $C$ in direct activation of phospholipase D1 through $\mathrm{G}$ protein-coupled receptor signaling. Mol. Biol. Cell 11, 4359-4368

$28 \mathrm{Yu}, \mathrm{B} ., \mathrm{Gu}, \mathrm{L}$. and Simon, M. I. (2000) Inhibition of subsets of G protein-coupled receptors by empty mutants of $\mathrm{G}$ protein alpha subunits in $\mathrm{g}(\mathrm{o}), \mathrm{G}(11)$, and $\mathrm{G}(16)$. J. Biol. Chem. 275, 71-76

29 Klein, J., lovino, M., Vakil, M., Shinozaki, H. and Loffelholz, K. (1997) Ontogenetic and pharmacological studies on metabotropic glutamate receptors coupled to phospholipase D activation. Neuropharmacol. 36, 305-311

30 Mitchell, P. R. and Martin, I. L. (1978) Is GABA release modulated by presynaptic receptors? Nature 274, 904-905

31 Mitchell, R., Robertson, D. N., Holland, P. J., Collins, D., Lutz, E. M. and Johnson, M. S. (2003) ADP-ribosylation factor-dependent phospholipase $D$ activation by the M3 muscarinic receptor. J. Biol. Chem. 278, 33818-33830

32 Lee, Y. C., Block, G., Chen, H., Folch-Puy, E., Foronjy, R., Jalili, R., Jendresen, C. B., Kimura, M., Kraft, E., Lindemose, S., Lu, J., McLain, T., Nutt, L., Ramon-Garcia, S., Smith, J., Spivak, A., Wang, M. L., Zanic M. and Lin, S. H. (2008) One-step isolation of plasma membrane proteins using magnetic beads with immobilized concanavalin A. Protein Expr. Purif. 62, 223229

33 Ichikawa, J. and Meltzer, H. Y. (1995) DOI, a 5-HT2A/2C receptor agonist, potentiates amphetamine-induced dopamine release in rat striatum. Brain Res. 698, 204-208

34 Pehek, E. A., Nocjar, C., Roth, B. L., Byrd, T. A. and Mabrouk, O. S. (2006) Evidence for the preferential involvement of 5-HT2A serotonin receptors in stress- and drug-induced dopamine release in the rat medial prefrontal cortex. Neuropsychopharmacol. 31, 265-277

Scott, S. A., Selvy, P. E., Buck, J. R., Cho, H. P., Criswell, T. L., Thomas, A. L., Armstrong, M. D., Arteaga, C. L., Lindsley, C. W. and Brown, H. A. (2009) Design of isoform-selective phospholipase D inhibitors that modulate cancer cell invasiveness. Nat. Chem. Biol. 5, 108-117 Lavieri, R., Scott, S. A., Lewis, J. A., Selvy, P. E., Armstrong, M. D., Brown, A. H. and Lindsley, C. W. (2009) Design and synthesis of isoform-selective phospholipase D (PLD) inhibitors. Part II. Identification of the 1,3,8-triazaspiro[4,5]decan-4-one privileged structure that engenders PLD2 selectivity. Bioorg. Med. Chem. Lett. 19, 2240-2243

37 Schmidt, M., Huwe, S. M., Fasselt, B., Homann, D., Rumenapp, U., Sandmann, J. and Jakobs, K. H. (1994) Mechanisms of phospholipase D stimulation by m3 muscarinic acetylcholine receptors. Evidence for involvement of tyrosine phosphorylation. Eur. J. Biochem. 225, 667675 
Hanke, J. H., Gardner, J. P., Dow, R. L., Changelian, P. S., Brissette, W. H., Weringer, E. J., Pollok, B. A. and Connelly, P. A. (1996) Discovery of a novel, potent, and Src family-selective tyrosine kinase inhibitor. Study of Lck- and Fyn-dependent T cell activation. J. Biol. Chem. 271, 695-701

39 Tian, G., Cory, M., Smith, A. A. and Knight, W. B. (2001) Structural determinants for potent, selective dual site inhibition of human pp60c-src by 4-anilinoquinazolines. Biochem. 40, 70847091

40 Hammond, S. M., Jenco, J. M., Nakashima, S., Cadwallader, K., Gu, Q., Cook, S., Nozawa, Y., Prestwich, G. D., Frohman, M. A. and Morris, A. J. (1997) Characterization of two alternately spliced forms of phospholipase D1. Activation of the purified enzymes by phosphatidylinositol 4,5-bisphosphate, ADP-ribosylation factor, and Rho family monomeric GTP-binding proteins and protein kinase C-alpha. J. Biol. Chem. 272, 3860-3868

41 Lehmann, D. M., Seneviratne, A. M. and Smrcka, A. V. (2008) Small molecule disruption of G protein beta gamma subunit signaling inhibits neutrophil chemotaxis and inflammation. Mol. Pharmacol. 73, 410-418

42 Du, G., Altshuller, Y. M., Vitale, N., Huang, P., Chasserot-Golaz, S., Morris, A. J., Bader, M. F. and Frohman, M. A. (2003) Regulation of phospholipase D1 subcellular cycling through coordination of multiple membrane association motifs. J. Cell Biol. 162, 305-315

43 Zeniou-Meyer, M., Zabari, N., Ashery, U., Chasserot-Golaz, S., Haeberle, A. M., Demais, V., Bailly, Y., Gottfried, I., Nakanishi, H., Neiman, A. M., Du, G., Frohman, M. A., Bader, M. F. and Vitale, N. (2007) Phospholipase D1 production of phosphatidic acid at the plasma membrane promotes exocytosis of large dense-core granules at a late stage. J. Biol. Chem. 282, 2174621757

44 Du, G., Huang, P., Liang, B. T. and Frohman, M. A. (2004) Phospholipase D2 localizes to the plasma membrane and regulates angiotensin II receptor endocytosis. Mol. Biol. Cell 15, 10241030

45 Rankovic, M., Jacob, L., Rankovic, V., Brandenburg, L. O., Schroder, H., Hollt, V. and Koch, T. (2009) ADP-ribosylation factor 6 regulates mu-opioid receptor trafficking and signaling via activation of phospholipase D2. Cell. Signal. 21, 1784-1793

46 Rizzo, M. and Romero, G. (2002) Pharmacological importance of phospholipase D and phosphatidic acid in the regulation of the mitogen-activated protein kinase cascade. Pharmacol. Ther. 94, 35-50

47 Garrido, J. L., Wheeler, D., Vega, L. L., Friedman, P. A. and Romero, G. (2009) Role of phospholipase $\mathrm{D}$ in parathyroid hormone type 1 receptor signaling and trafficking. Mol. Endocrinol. 23, 2048-2059

48 Perez-Mansilla, B., Ha, V. L., Justin, N., Wilkins, A. J., Carpenter, C. L. and Thomas, G. M. (2006) The differential regulation of phosphatidylinositol 4-phosphate 5-kinases and phospholipase D1 by ADP-ribosylation factors 1 and 6. Biochim. Biophys. Acta 1761, 14291442

49 Cockcroft, S. (2009) Phosphatidic acid regulation of phosphatidylinositol 4-phosphate 5kinases. Biochim. Biophys. Acta 1791, 905-912 


\section{TABLES AND FIGURES}

Table 1 Negative mutant $\mathrm{G} \alpha_{q}$ does not inhibit PLD responses of the $5-\mathrm{HT}_{2 A} \mathrm{R}$ but does inhibit

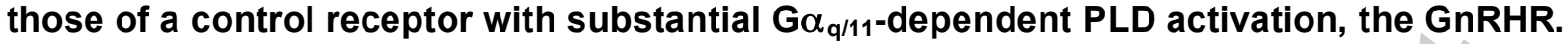

\begin{tabular}{|c|c|c|c|c|}
\hline \multirow{2}{*}{ Receptor } & \multicolumn{4}{|c|}{$\begin{array}{c}\text { Agonist-induced }{ }^{3} \mathrm{H} \text { ]PtdBut production } \\
\text { fold increment over unstimulated control) }\end{array}$} \\
\cline { 2 - 5 } & Empty vector & $\begin{array}{c}\text { G } \alpha_{q} \text { (GIn209Leu/ } \\
\text { Asp277Asn) plus } \\
\text { empty vector }\end{array}$ & $\begin{array}{c}\text { PLD1 plus } \\
\text { empty vector }\end{array}$ & $\begin{array}{c}\text { PLD1 plus } \\
\text { (Gln209Leu/ } \\
\text { Asp277Asn) }\end{array}$ \\
\hline $\mathrm{h} 5-\mathrm{HT}_{2 \mathrm{~A}} \mathrm{R}$ & $2.13 \pm 0.23$ & $1.90 \pm 0.22$ & $7.12 \pm 1.46^{*}$ & $5.76 \pm 0.56^{*}$ \\
\hline $\mathrm{mGnRHR}$ & $3.38 \pm 0.45$ & $0.98 \pm 0.12^{+}$ & $8.83 \pm 1.11^{*}$ & $3.84 \pm 0.53^{\dagger}$ \\
\hline
\end{tabular}

PLD responses to $3 \mu \mathrm{M} 5-\mathrm{HT}$ or $300 \mathrm{nM} \mathrm{GnRH}$ were measured in COS7 cells transfected with 5$\mathrm{HT}_{2 \mathrm{~A}} \mathrm{R}$ or $\mathrm{GnRHR}$, in the presence or absence of PLD1 and $\mathrm{G} \alpha_{q}$ (GIn209Leu/Asp277Asn) or empty vector (pcDNA3.1). * Indicates response significantly greater than that in the absence of additional PLD1 and ${ }^{\dagger}$ indicates response significantly less than that in the absence of $\mathrm{G} \alpha_{q}(G \ln 209 L e u /$ Asp277Asn) ( $p<0.05$, Wilcoxon test, $n=8)$.

Table 2 Lack of effect of a range of signalting pathway inhibitors on 5-HT-induced PLD responses of $5-\mathrm{HT}_{2 \mathrm{~A}} \mathrm{R}$-expressing cells.

\begin{tabular}{|c|c|c|}
\hline \multirow[t]{2}{*}{ Condition } & \multicolumn{2}{|c|}{$\begin{array}{l}\text { 5-HT }(3 \mu \mathrm{M}) \text { - induced }\left[{ }^{3} \mathrm{H}\right] \mathrm{PtdBut} \text { production } \\
\text { (fold increment over unstimulated control) }\end{array}$} \\
\hline & 5- $\mathrm{HT}_{2 \mathrm{~A}} \mathrm{R}$ plus empty vector & 5- $\mathrm{HT}_{2 \mathrm{~A}} \mathrm{R}$ plus PLD1 \\
\hline a) control & $2.43 \pm 0.26$ & $4.91 \pm 0.53$ \\
\hline U73122 (20 $\mu \mathrm{M})$ & $3.11 \pm 0.48$ & $5.40 \pm 0.69$ \\
\hline AG213 (100 $\mu \mathrm{M})$ & $3.01 \pm 0.33$ & $5.12 \pm 0.78$ \\
\hline Genistein $(80 \mu \mathrm{M})$ & $2.31 \pm 0.40$ & $4.81 \pm 0.66$ \\
\hline b) control & $2.83 \pm 0.36$ & $6.12 \pm 0.72$ \\
\hline PP1 (10 $\mu \mathrm{M})$ & $2.53 \pm 0.21$ & $5.55 \pm 0.70$ \\
\hline PP2 (5 $\mu \mathrm{M})$ & $2.40 \pm 0.33$ & $5.78 \pm 0.41$ \\
\hline PP3 $(5 \mu \mathrm{M})$ & $2.71 \pm 0.34$ & $5.99 \pm 0.60$ \\
\hline Src-inhibitor1 $(20 \mu \mathrm{M})$ & $3.01 \pm 0.37$ & $5.40 \pm 0.63$ \\
\hline
\end{tabular}


C) control

BIM-1 (3 $\mu \mathrm{M})$

CGP 41251 (3 $\mu \mathrm{M})$

Pertussis toxin $(200 \mathrm{ng} / \mathrm{ml})$

Gallein $(10 \mu \mathrm{M})$
$2.95 \pm 0.33$

$3.24 \pm 0.39$

$2.53 \pm 0.61$

$3.06 \pm 0.44$

$2.70 \pm 0.31$
$6.82 \pm 0.83$

$6.13 \pm 0.91$

$7.01 \pm 0.53$

$6.19 \pm 0.71$

$6.21 \pm 0.65$

PLD responses to $3 \mu \mathrm{M} 5-\mathrm{HT}$ were measured in COS7 cells transfected with $5-\mathrm{HT}_{2 \mathrm{~A}} \mathrm{R}$ and empty vector (pcDNA3.1) or additional wild-type PLD1. In the case of pertussis toxin, cells were preincubated for $16 \mathrm{~h}$. No significant differences from corresponding control responses were detected by Wilcoxon test, $n=6$. a), b) and c) denote different experimental series.

Table 3 Negative mutant RhoA does not inhibit 5-HT-induced PLD responses in 5-HT $2 A$ expressing cells but does inhibit responses mediated by the native thrombin receptor.

\begin{tabular}{|l|c|c|c|c|}
\hline \multirow{2}{*}{ Agonist } & \multicolumn{3}{|c|}{$\begin{array}{c}\text { Agonist - induced }{ }^{3} \mathrm{H} \text { HPtdBut production } \\
\text { (fold increment over unstimulated control) }\end{array}$} \\
\cline { 2 - 5 } & Empty vector & $\begin{array}{c}\text { Empty vector plus } \\
\text { RhoA(Thr19Asn) }\end{array}$ & $\begin{array}{c}\text { PLD1 plus } \\
\text { empty vector }\end{array}$ & $\begin{array}{c}\text { PLD1 plus } \\
\text { RhoA(Thr19Asn) }\end{array}$ \\
\hline $5-\mathrm{HT}(3 \mu \mathrm{M})$ & $2.63 \pm 0.35$ & $2.72 \pm 0.28$ & $5.68 \pm 0.97$ & $5.33 \pm 0.69$ \\
\hline $\begin{array}{l}\text { Thrombin } \\
(0.5 \mathrm{U} / \mathrm{ml})\end{array}$ & $3.13 \pm 0.42$ & $2.38 \pm 0.39$ & $4.72 \pm 0.51$ & $2.58 \pm 0.37^{*}$ \\
\hline
\end{tabular}

PLD responses to $3 \mu \mathrm{M} 5-\mathrm{HT}$ or $0.5 \mathrm{U} / \mathrm{ml}$ thrombin were measured in COS7 cells transfected with 5$\mathrm{HT}_{2 \mathrm{~A}} \mathrm{R}$ and empty vector (pcDNA3.1) or wild-type PLD1 in the absence or presence of RhoA(Thr19Asn). * Indicates response significantly different from corresponding response in the absence of RhoA(Thr19Asn), $p<0.05$, Wilcoxon test, $n=6$.

Table 4 Amplification of 5-HT-induced PLD responses in 5-HT ${ }_{2 A}$-expressing cells by additional wild type PLD1 is mimicked by a RhoA/PKC-unresponsive, ARF-selective, PLD1 construct.

\begin{tabular}{|c|c|c|c|}
\hline \multirow{2}{*}{ Activator } & \multicolumn{3}{|c|}{$\begin{array}{c}\left.\text { Activator-induced }{ }^{3} \mathrm{H}\right] \text { PtdBut production } \\
\text { (fold increment over unstimulated control) }\end{array}$} \\
\cline { 2 - 4 } & Empty vector & PLD1 & PLD1(PIM87/Ile870Arg) \\
\hline 5-HT $(3 \mu \mathrm{M})$ & $1.85 \pm 0.10$ & $6.08 \pm 0.58^{*}$ & $5.27 \pm 0.67^{*}$ \\
\hline PDBu $(300 \mathrm{nM})$ & $4.64 \pm 0.42$ & $9.79 \pm 0.88^{*}$ & $3.93 \pm 0.48^{\dagger}$ \\
\hline
\end{tabular}

PLD responses to $3 \mu \mathrm{M} 5-\mathrm{HT}$ or $300 \mathrm{nM}$ phorbol 12,13-dibutyrate (PDBu) were measured in COS7 cells transfected with 5- $\mathrm{HT}_{2 \mathrm{~A}} \mathrm{R}$ and empty vector (pcDNA3.1), wild type PLD1 or PLD1(PIM87/lle870Arg). * Indicates response significantly greater than that in the presence of pcDNA3.1 and $^{\dagger}$ indicates response significantly less than that in the presence of wild type PLD1 ( $p<$ 0.05 , Wilcoxon test, $n=6-8$ ). 
Figure 1 5- $\mathrm{HT}_{2 \mathrm{~A}} \mathrm{R}$-mediated PLD activation in COS7 cells and prefrontal cortex predominantly involves the PLD1 isoform

$\left[{ }^{3} \mathrm{H}\right]$ PtdBut production in response to $5-\mathrm{HT}_{2 \mathrm{~A}} \mathrm{R}$ activation was determined in COS7 cells transfected with the 5- $\mathrm{HT}_{2 \mathrm{~A}} \mathrm{R}$ receptor and either a PLD construct or empty vector, (a)-(c) or in prefrontal cortex minislices, (d). Data shown are mean values \pm SEM $(n=5-8)$. (a) $5-\mathrm{HT}$-induced $\left[{ }^{3} \mathrm{H}\right] \mathrm{PtdB}$ t production

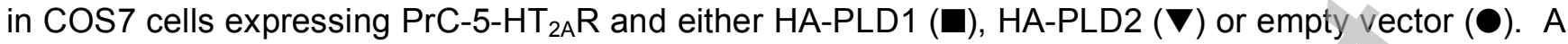
significant increase in PLD activation was observed at all time points following PLD1 expression only $\left({ }^{*} p<0.05\right.$, Friedman and Wilcoxon tests), with PLD2 having no discernible effect. (b) 5-HT-induced $\left[{ }^{3} \mathrm{H}\right]$ PtdBut production in COS7 cells expressing $\operatorname{PrC}-5-\mathrm{HT}_{2 \mathrm{~A}} \mathrm{R}$ and either the catalytically inactive mutants HA-PLD1(Lys898Arg) ( $\square$ ), HA-PLD2(Lys758Arg) $(\nabla)$ or empty vector (O). A significant reduction in PLD activity was observed at all time points following mutant PLD1 expression only $\left({ }^{*} p<\right.$ 0.05, Friedman and Wilcoxon tests), with mutant PLD2 having no discernible effect. (c) Neither wild type nor mutant PLD isoforms altered 5-HT-induced PLC activation (d) In prefrontal cortex minislices, $\left[{ }^{3} \mathrm{H}\right] \mathrm{PtdBut}$ production induced by the selective $5-\mathrm{HT}_{2} \mathrm{R}$ agonist $(\mathrm{R})-\mathrm{DOI}(3 \mu \mathrm{M})$ was inhibited by the highly selective $5-\mathrm{HT}_{2 \mathrm{~A}} \mathrm{R}$ antagonist M100907 (MDL; $0.5 \mu \mathrm{M}$ ) and by the selective PLD1 inhibitor VU $0155069(\mathrm{VU} ; 0.5 \mu \mathrm{M})$ but not by the selective PLD2 inhibitor BML 280 (BML; $5 \mu \mathrm{M})$. ( $\mathbf{\dagger}<<0.05$, Wilcoxon test, $\mathrm{n}=5)$.

Figure 2 PLD1 directly associates with the 5-HT $2 \mathrm{~A}$ in plasma membranes at a site in its carboxy-terminal domain

COS7 cells were co-transfected with PrC-5- $\mathrm{HT}_{2 \mathrm{~A}} \mathrm{R}$ and HA-PLD1 for immunoprecipitation experiments. (a) Anti-PrC antibody (or non-immune IgG; $\mathrm{NI} I g G$ ) was used to pull-down PrC-5- $\mathrm{HT}_{2 \mathrm{~A}} \mathrm{R}$ from cell lysates, with levels of HA-PLD1 input, immunoprecipitated $5-\mathrm{HT}_{2 \mathrm{~A}} \mathrm{R}$ and co-immunoprecipitated HAPLD1 shown in the upper, middle and lower panels. The middle and lower panels show corresponding lanes from an individual gel probed for PrC or HA tag. The upper panel (HA-PLD1 input) represents other lanes from the same gel. HA-PLD1 clearly associated with the immunoprecipitated receptor, with minimal interaction observed in the non-immune controls (results typical of 5 separate experiments). (b) In COS7 cells co-transfected with PrC-5-HT $2 \mathrm{~A}$ and HA-PLD1, a plasma membrane fraction was captured by concanavalin A-biotin linked to streptavidin-conjugated magnetic beads before elution, $\mathrm{HA}$-directed immunoprecipitation and $\left[{ }^{3} \mathrm{H}\right]$ ketanserin binding to the $5-\mathrm{HT}_{2 \mathrm{~A}} \mathrm{R}$. Significantly greater specific $\left[{ }^{3} \mathrm{H}\right]$ ketanserin binding $\left({ }^{*} p<0.05\right.$, Wilcoxon test) was found compared to non-immune IgG controls in the plasma membrane but not the non-plasma membrane fractions $(n=5)$. Compared to the total specific binding recovered from a control solubilisation and capture procedure on unfractionated membranes (903 $\pm 98 \mathrm{dpm}$ per assay), mean specific binding to HA-directed immunoprecipitates and non-immune controls represented $37.8 \%$ and $14.5 \%$ respectively for the plasma membrane fraction and $25.1 \%$ and $16.1 \%$ for the non-plasma membrane flow through. Non-specific binding fell within the range 240-310 dpm per assay. (c) GST-fusion proteins of 5- $\mathrm{HT}_{2 \mathrm{~A}} \mathrm{R}$ domains were captured on glutathione-sepharose and incubated with lysates from COS7 cells transfected with HA-PLD1. A typical blot is shown, with input levels of GST constructs (GST-5-HT $2 \mathrm{~A}$ Rct(376-471), $40 \mathrm{kDa}$; GST-5$\mathrm{HT}_{2 \mathrm{~A}} \operatorname{Rct}(385-471), 39 \mathrm{kDa}$; GST-5-HT $2 \mathrm{~A} \mathrm{Ri}$ (258-326), $36 \mathrm{kDa}$, GST alone, $29 \mathrm{kDa}$ ) displayed in the lower panel. Binding of HA-PLD1 to each of the GST constructs is shown in the upper panel, with the most robust interactions occurring with the 5- $\mathrm{HT}_{2 \mathrm{~A}} \mathrm{Rct}(385-471)$ construct. Minimal interaction was detected between PLD1 and GST alone. The bar chart illustrates results from densitometric analysis of results from the similar blots Significant increases in partner protein binding compared to their association with the GST-5- $\mathrm{HT}_{2 \mathrm{~A}} \operatorname{Rct}(376-471)$ construct are shown ( ${ }^{*} \mathrm{p}<0.05$, Wilcoxon test, $\mathrm{n}=5$ $6)$.

Figure 3 Identification of regions in the 5- $\mathrm{HT}_{2 \mathrm{~A}}$ Rct important for interactions with PLD1 GST-fusion proteins of the full length 5- $\mathrm{HT}_{2 \mathrm{~A}} \mathrm{Rct}$ domain (376-471) and three carboxy-terminally truncated constructs (376-470), (376-438) and (376-428) were examined for interactions with HAPLD1 and ARF1-HA from enriched cell lysates. $A$ representative blot is shown alongside 
corresponding bar charts produced from densitometric analysis of 5 experiments. Both HA-PLD1 and ARF1-HA associated with the full-length ct construct (376-471). Removal of residue 471 (i.e. the 376470 construct) resulted in a small reduction in the level of HA-PLD1 bound and larger reductions were detected upon further ct truncation, as shown with the (376-438) and (376-428) constructs. In contrast, no differences in ARF1-HA association were apparent between the full length and the truncated carboxy-terminal constructs $(t p<0.05$, Wilcoxon test; $n=5)$.

\section{Figure 4 HA-PLD1 and ARF1-HA associate separately with the GST-5-HT $2 \mathrm{Rct}$}

Aliquots of the full length GST-5- $\mathrm{HT}_{2 \mathrm{~A}} \mathrm{Rct}(376-471)$ construct were captured on glutathione-sepharose and subjected to two $12 \mathrm{~h}$ incubations with combinations of lysates from cells transfected with ARF1HA or HA-PLD1, and the corresponding lysis buffers as indicated. Input levels of GST-5-HT $2 \mathrm{~A} R \operatorname{ct}(376-$ 471) are shown in the lower panel. In the left panels the level of HA-PLD1 associated with the 5$\mathrm{HT}_{2 \mathrm{~A}}$ Rct construct appeared to be unaffected following a second incubation period with either ARF1HA lysate or ARF lysis buffer. Conversely, the degree of ARF1-HA interaction with the 5$\mathrm{HT}_{2 \mathrm{~A}}$ Rct(376-471) construct was not changed by the prior association of HA-PLD1 with the construct. Similarly, in the right panels the ARF1-HA and GST-5-HT $2 \mathrm{~A} \operatorname{Rct}(376-471)$ interaction was neither altered by, nor altered the subsequent association of HA-PLD1 with the receptor construct. 
Figure 1

a)

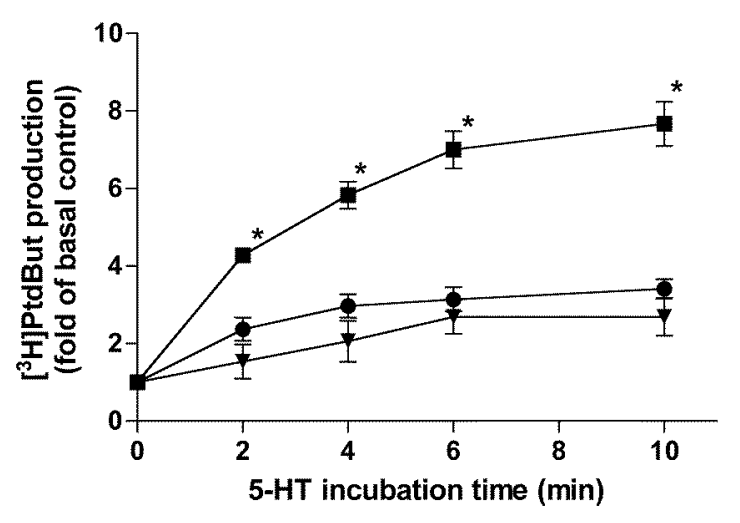

c)

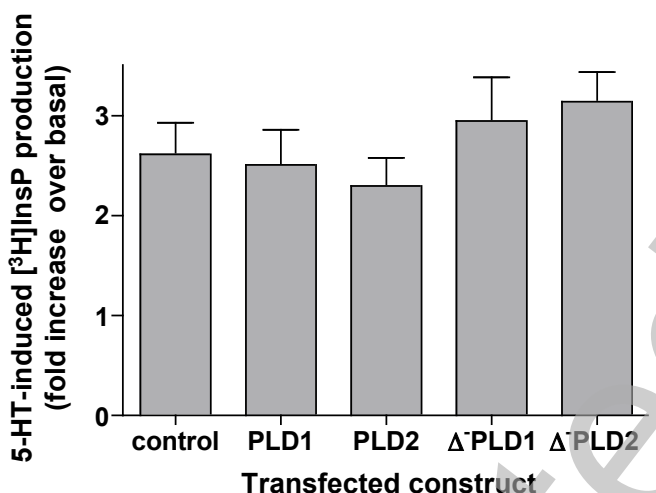

b)

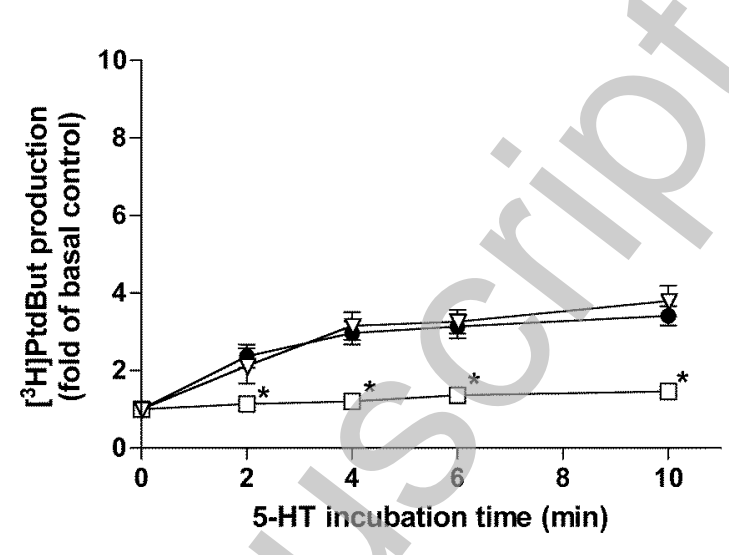

d)

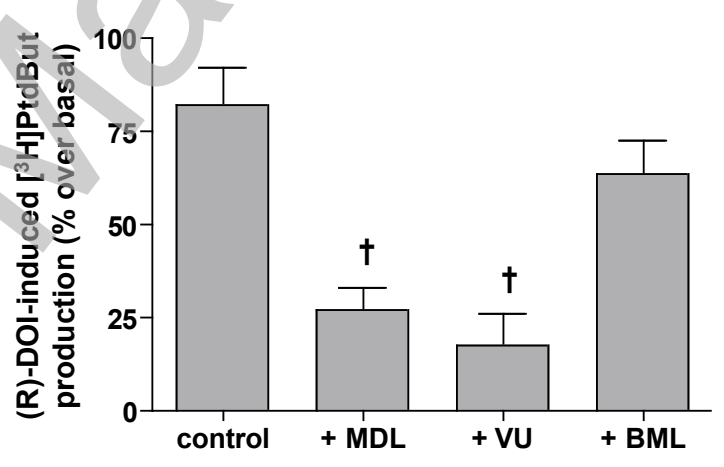


Figure 2

a)

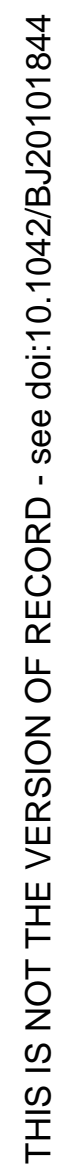

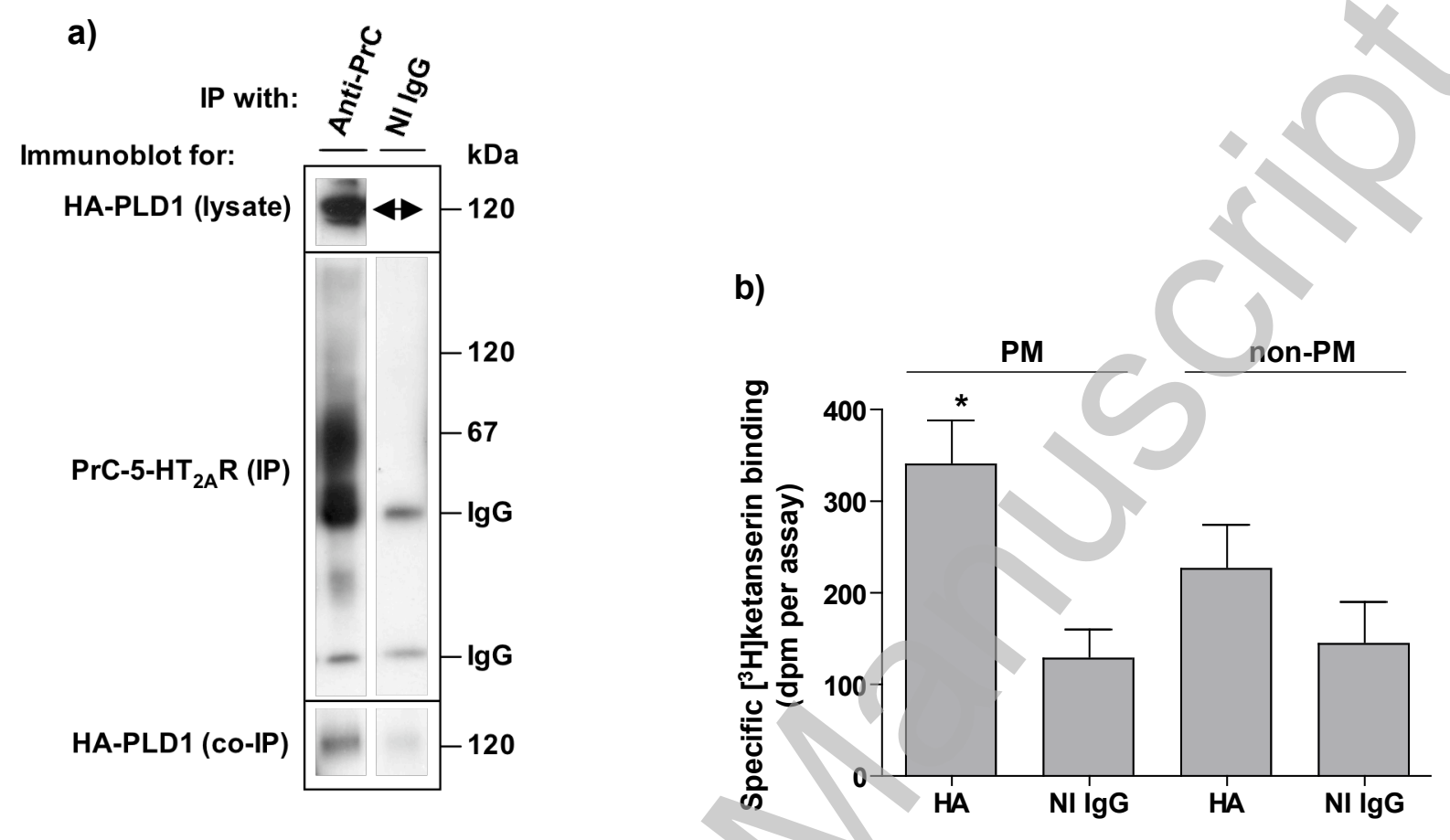

c)
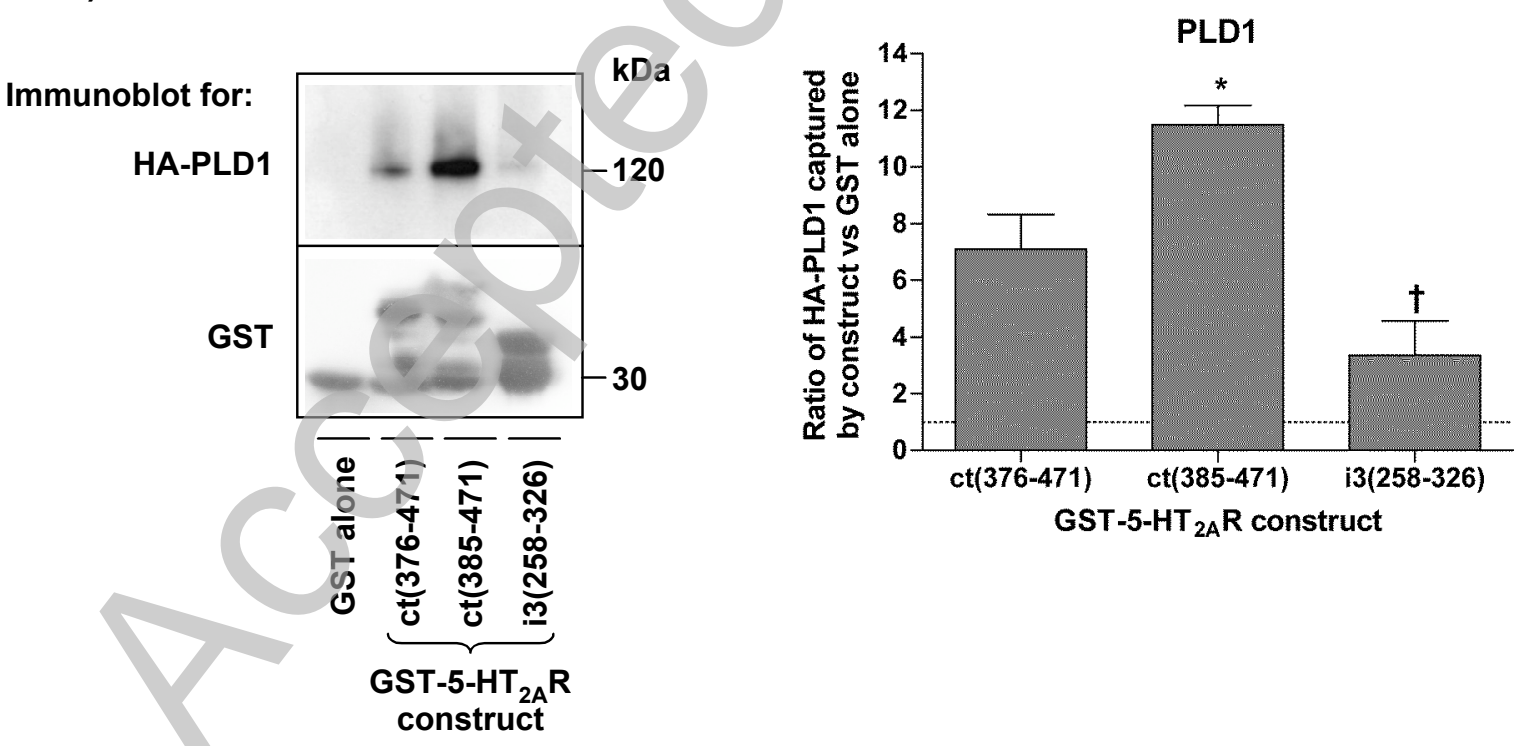
Figure 3

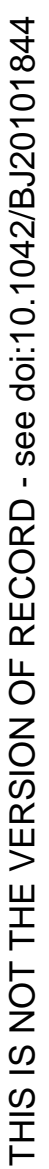

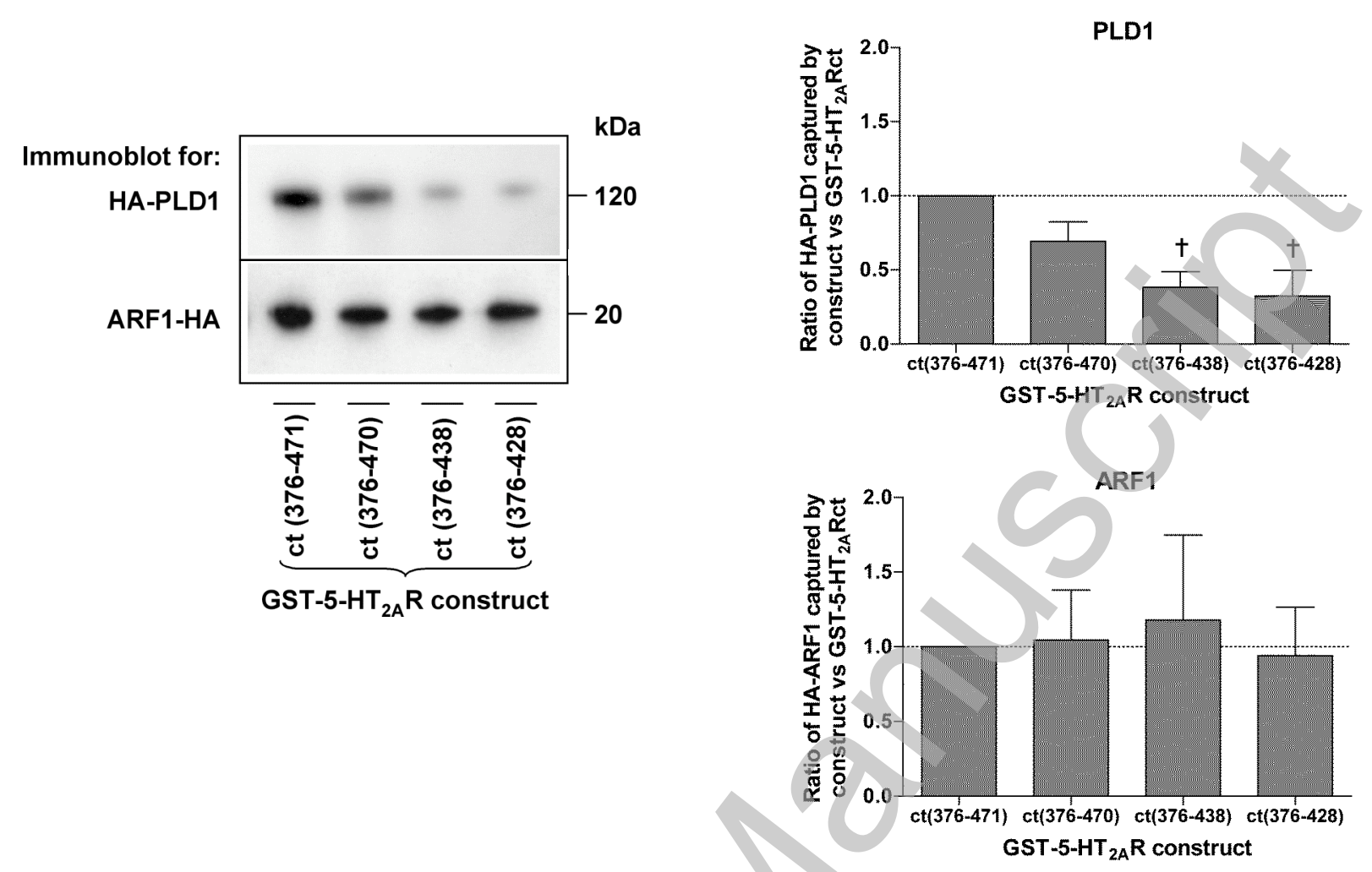


Figure 4
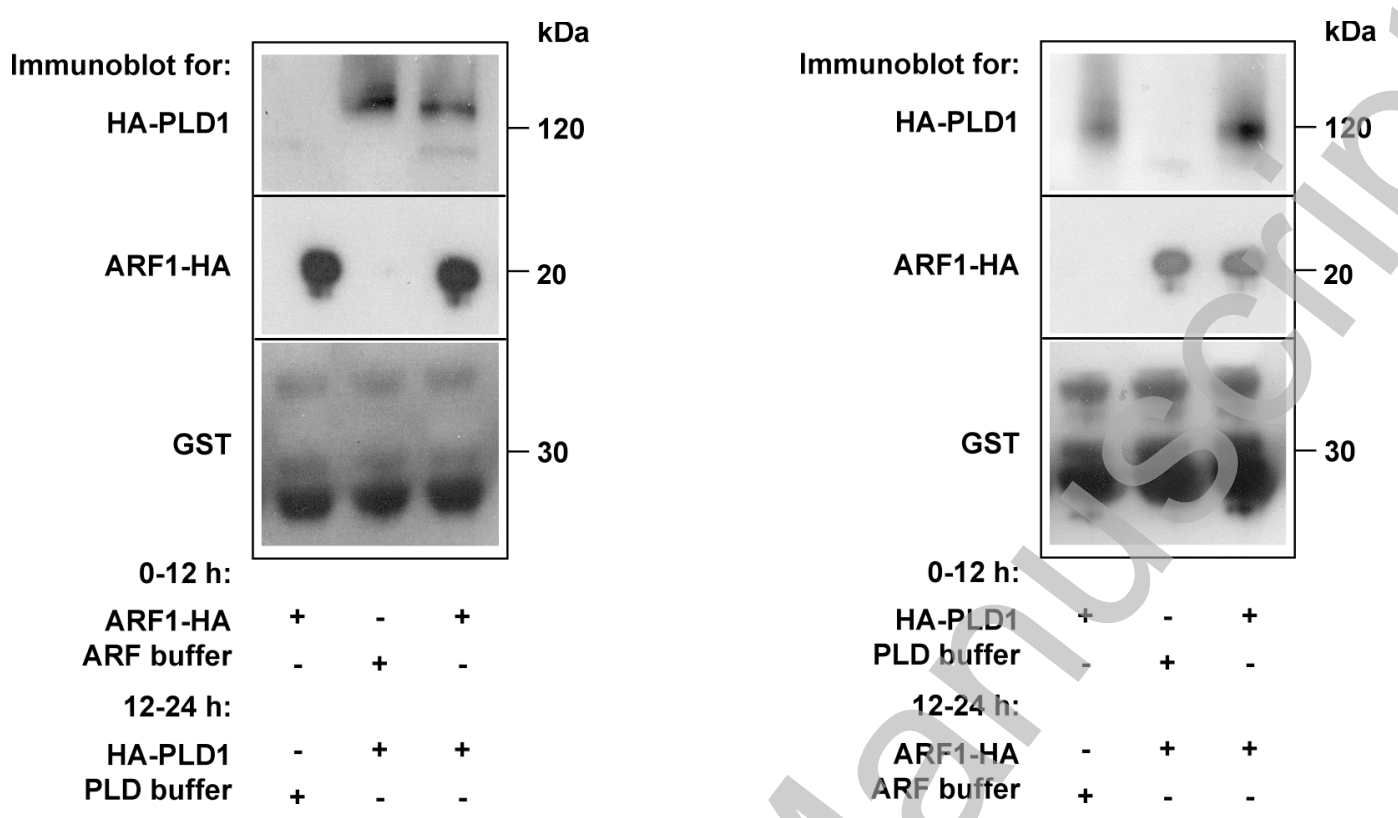